\title{
One More Resource Curse: Dutch Disease and Export Concentration
}

\author{
Dany Bahar and Miguel A. Santos \\ CID Research Fellow and Graduate Student \\ Working Paper No. 68 \\ May 2016 (Revised Dec. 2017)
}

Copyright 2016 Bahar, Dany; Santos, Miguel; and the

President and Fellows of Harvard College

\section{Working Papers \\ Center for International Development at Harvard University}




\title{
One more resource curse: Dutch disease and
}

\section{export concentration*}

\author{
Dany Bahar ${ }^{\dagger}$ Miguel A. Santos \\ Brookings Institution Harvard CID \\ Harvard CID
}

December 18, 2017

[Download Newest Version]

Keywords: Concentration, diversification, exports, natural resources, Dutch disease, capital intensity.

JEL Classification Numbers: F14, F43, O11, O13, Q33

${ }^{*}$ The authors would like to thank the editor and referees for their insightful comments. We also thank Ricardo Hausmann, Dani Rodrik, Sebastian Bustos and Xavier Raurich for useful comments and suggestions, as well as to participants of different seminars of the Center for International Development at Harvard University and Universidad de Barcelona. The usual disclaimers apply. We thank Eric Carlson, Luis Omar Herrera and Brina Seidel for excellent research assistance. All errors are our own.

${ }^{\dagger}$ Corresponding Author: 1775 Massachusets Ave Washington DC 20001 USA; db21@post.harvard.edu 


\begin{abstract}
Economists have long discussed the negative effect of Dutch disease episodes on the non-resource tradable sector as a whole, but little has been said on its impact on the composition of the non-resource export sector. This paper fills this gap by exploring to what extent concentration of a country's non-resource export basket is determined by their exports of natural resources. We present a theoretical framework that shows how upward pressure in wages caused by a resource windfall results in higher export concentration. We then document two robust empirical findings consistent with the theory. First, using data on discovery of oil and gas fields and of commodity prices as sources of exogenous variation, we find that countries with larger shares of natural resources in exports have more concentrated non-resource export baskets. Second, we find capital-intensive exports tend to dominate the export basket of countries prone to Dutch disease episodes.
\end{abstract}




\section{Introduction}

The literature on Dutch disease is extensive when it comes to documenting the negative impacts of natural resource exports on non-resource tradable goods as an aggregate (e.g., Corden and Neary, 1982; Corden, 1984; Sachs and Warner, 1995). Little has been said on the impact of natural resources on non-resource export concentration. And yet, different branches of the economic literature have documented the beneficial impacts of export diversification on various grounds (e.g., Imbs and Wacziarg, 2003, Klinger and Lederman, 2004; Hausmann et al., 2007; Hidalgo et al., 2007; Koren and Tenreyro, 2007; Cadot et al., 2011). This study lies at the junction of these two strands of the economic literature, as it explores and documents non-resource export basket concentration in countries suffering Dutch disease episodes.

To explore this question we first describe a theoretical framework of heterogenous firms in two sectors -a labor-intensive one and a capital-intensive one- that models the impact of a resource windfall on export diversification, following the seminal works of Melitz (2003) and of Bernard et al. (2007) 1 1 In our framework a resource windfall increases domestic expenditure which puts upward pressure on wages, thus affecting the competitiveness of exporting firms particularly in the labor intensive sector. Given that we model each firm as having a different productivity parameter and as exporting a different variety, these dynamics result in a lower set of varieties being exported to the foreign economy. A resource windfall thus leads to higher

\footnotetext{
${ }^{1}$ Other papers that model the economic implications of Dutch disease in the context of a Melitz (2003) framework are Van der Ploeg and Venables (2013); Beine et al. (2015); Ostenstad and Vermeulen (2016).
} 
export concentration.

We test these dynamics using international trade data for 128 countries and 27 years. Using this data we estimate the impact of Dutch disease on non-resource export concentration. In particular, we test the impacts of the share of natural resources in exports on a number of non-resource export concentration indexes: Gini coefficient, Herfindahl-Hirschman index, the number of active export products or varieties, and the Theil index. The use of the Theil index allows us to explore whether the concentration is occurring more at the extensive margin (numbers of products or varieties exported) or intensive margin (changes in the relative size of already existing products). We use multiple indexes to ensure that our findings are not dependent on the particular way in which export concentration is measured.

We find a consistent and significant negative relation between the share of natural resources in exports and non-resource export concentration: Countries more prone to suffer from Dutch disease tend to have more concentrated non-resource export baskets. In order to deal with endogeneity concerns, we present a number of results that shed light on the causal direction of the relationship. In particular, we make use of data on commodity prices and on discovery of oil and gas fields to instrument for the share of natural resource exports in an economy, and find that a larger share of natural resource exports increases non-resource export concentration. In addition, using a difference-in-differences framework, we also find larger non-resource export concentration occurs in countries experiencing increases in exports of natural resources due to unusual commodity price fluctuations. Our results suggest that countries with roughly one standard deviation in the share of natural 
resources in total exports above average tend to higher non-resource export concentration of up to one-half standard deviation measured through the different concentration indexes. This relationship is quite consistent across very different empirical methods used in the paper. We also find that most of the impact on the Theil index is due to changes in the relative size of existing products (the intensive margin), and not due to changes in the closing of product lines (the extensive margin). All in all, we consistently find that these results are predominantly driven by developing countries.

We then dig deeper into the non-resource export basket of countries to test another prediction from the theoretical framework: Labor-intensive varieties are more affected by a resource windfall. To explore this relationship we use export data at the country-product-year level, together with product-level indicators on capital intensity from NBER's productivity dataset (Becker et al. 2013), considering about 600 different non-natural resource products. Our findings indicate that countries prone to suffer from Dutch disease tend to be more concentrated towards capital-intensive export products, as opposed to labor-intensive ones. We also find that this concentration towards capital-intensive goods is non-linear, and responds to a U-shaped curve that depends on the initial level of the overall capital content of the export basket, as measured by sum of product-level capital intensity weighted by each product's share in the export basket. Intuitively, if a country has none to very few capital-intensive products in its export basket, then a resource windfall at first would be correlated with diversification towards capital-intensive products. However, above certain threshold of capital content in the export basket, it is concentration what follows a 
resource windfall. For the vast majority of the country-year pairs in the sample, however, the capital content of their export basket already stands above this threshold.

Our paper can be framed within the early economic literature studying Dutch disease, a condition likely to show up in resource abundant countries, and can be framed within the literature that evolved after the seminal works by Neary (1982) and Corden and Neary (1982), who discuss the ways through which Dutch disease impacts the economy. Within the context of Dutch disease, our paper also contributes to the literature studying different drivers of export diversification (e.g., Imbs and Wacziarg, 2003; Hausmann et al., 2007; Hidalgo et al., 2007; Cadot et al., 2011; Bahar et al., 2014; Bahar and Rapoport, 2018; Bahar et al., 2017).

The paper is organized as follows: Section 2 describes a theoretical framework that links export diversification to Dutch disease dynamics. Section 3 presents the data, and provides some stylized facts. Section 4 contains our regressions at the country-year level and presents results on the positive relationship between larger shares of natural resources in exports and our different measures of non-resource export concentration. These results use a number of different econometric estimation techniques that deal with endogeneity issues. Section 5 looks into another set of predictions from the theoretical framework using data at the country-product-year level, in particular shedding light on dynamics of capital-intensive export products following episodes of Dutch disease. Conclusions and policy implications are presented in Section 6 . 


\section{Theoretical Framework}

To analyze the impact of a resource windfall, we model a small open economy consisting of two industries, one of which is labor-intensive while the other is capital-intensive. Both industries consist of heterogeneous firms producing differentiated products. Labor in the economy is supplied inelastically and the total supply of labor is fixed. Workers can move at zero cost across firms and across industries but cannot move across countries. Capital, on the other hand, is bought and sold on the world market and firms in the small open economy act as price takers. The only sources of income are wages, rent from capital and an exogenous resource windfall.

Production in both the domestic market and the export market involves the payment of sunk costs which depends on the factor content of production as in Bernard et al. (2007). In addition, firms incur in transport costs on each unit of product sold abroad. As in Melitz (2003), these costs imply that only the most productive firms can afford to export. A resource windfall increases domestic expenditure which, given the fixed labor supply, puts upward pressure on wages as firms try to meet the increased consumer demand. This raises unit costs and leads to a more concentrated export basket because foreign expenditure remains unchanged. Furthermore, because the labor-intensive industry is more sensitive to changes in wages, the effect of a windfall is greater for this industry than for the capital-intensive industry. 


\subsection{Preferences and demand}

As in Bernard et al. (2007), consumers maximize

$$
U=\sqrt{C_{1} C_{2}}
$$

subject to $P_{1} C_{1}+P_{2} C_{2} \leq Y$. Let $L$ be the fixed supply of labor, let $K^{H}$ be the domestic supply of capital, $w$ be wage payments to labor, and $r$ be the rental rate of capital. National income $Y$ is the sum of total labor income, total capital income, and an exogenous windfall $Z$ and is given by $Y=w L+r K^{H}+Z$. The values $C_{1}$ and $C_{2}$ are industry-level aggregates of output from individual firms. Formally,

$$
C_{i}=\left(\int_{\omega \in \Omega_{i}} q(\omega)^{\frac{\sigma-1}{\sigma}} d \omega\right)^{\frac{\sigma}{\sigma-1}}
$$

for $i \in\{1,2\}$ where $\Omega_{i}$ represents the set of varieties produced in industry $i, q(\omega)$ is the quantity of variety $\omega$ produced, and $\sigma>1$. The utility function (1) implies that a constant share of income will be spent in each industry. Expenditure on industry $i$ is therefore given by $E_{i}=Y / 2$. Using the aggregator (2) yields the demand function

$$
q_{i}(\omega)=E_{i} P_{i}^{\sigma-1} p_{i}(\omega)^{-\sigma}
$$

where $P_{i} \equiv\left(\int_{\omega \in \Omega_{i}} p(\omega)^{1-\sigma}\right)^{\frac{1}{1-\sigma}}$ is an industry-level price index. 


\subsection{Production}

Firms in each industry $i$ use labor $(l)$ and capital $(k)$ in fixed-proportions with production given by:

$$
q_{i}(l, k ; \phi)=\phi \min \left[\frac{l}{\beta_{i}}, \frac{k}{1-\beta_{i}}\right]
$$

Furthermore, as in Bernard et al. (2007) and Ostenstad and Vermeulen (2016), firms pay a fixed cost that depends on factor intensity. Let $f_{j}$ represent the fixed cost associated with entering market $j \in\{D, X\}$ where $D$ is the domestic market and $X$ is the export market $2^{2}$ The cost function for a firm in industry $i$ is:

$$
c_{i}(\phi)=\left(f_{j}-\frac{q}{\phi}\right)\left[\beta_{i} w+\left(1-\beta_{i}\right) r\right]
$$

Assuming that industry 1 is labor-intensive and industry 2 is capital-intensive, we have $\beta_{1}>\beta_{2}$.

Firms maximize profits such that:

$$
\pi(\phi)=(p-c(\phi)) q
$$

The demand curve (3), implies that prices will be a constant markup over unit costs with

$$
p_{i}(\phi)=\left(\frac{\sigma}{\sigma-1} \frac{W_{i}}{\phi}\right)
$$

where $W_{i} \equiv \beta_{i} w+\left(1-\beta_{i}\right) r$ is the unit cost associated with $\phi=1$.

\footnotetext{
${ }^{2}$ Consistent with this type of models, we assume that $\tau^{(\sigma-1)} f_{x}>f_{d}$.
} 
Finally, firms can choose to sell domestically or to export goods abroad. In order to export, firms pay iceberg transport costs $\tau>1$ for every unit of good sold abroad. Let $\pi_{D i}$ represent operating domestic profits in industry $i$, $\pi_{X i}$ represent operating export profits, let an $H$ superscript denote the home economy and let an $F$ superscript denote the foreign economy ${ }^{3}$ Operating profits are thus given by:

$$
\begin{aligned}
& \pi_{D i}(\phi)=E_{i}^{H}\left(P_{i}^{H}\right)^{\sigma-1} \zeta\left(\frac{W_{i}}{\phi}\right)^{1-\sigma} \\
& \pi_{X i}(\phi)=\tau^{1-\sigma} E_{i}^{F}\left(P_{i}^{F}\right)^{\sigma-1} \zeta\left(\frac{W_{i}}{\phi}\right)^{1-\sigma}
\end{aligned}
$$

where $\zeta \equiv \sigma^{-\sigma}(\sigma-1)^{1-\sigma}$.

\subsection{Equilibrium}

Firms only produce if they can make non negative profits. The cutoff condition for domestic production is given by:

$$
E_{i}^{H}\left(P_{i}^{H}\right)^{\sigma-1} \zeta\left(\frac{W_{i}}{\phi_{D}}\right)^{1-\sigma}=f_{D} W_{i}
$$

and the cutoff condition for exporting is given by:

$$
\tau^{1-\sigma} E_{i}^{F}\left(P_{i}^{F}\right)^{\sigma-1} \zeta\left(\frac{W_{i}}{\phi_{X}}\right)^{1-\sigma}=f_{X} W_{i}
$$

To enter the industry, firms pay a sunk entry cost $f_{E} W_{i}$ to draw productivity parameter $\phi$ from the distribution $G(\phi)$. Let $\mu(\phi)=\frac{G(\phi)}{1-G\left(\phi_{D}\right)}$ be the distribution of $\phi$ conditional on successful entry. Potential entrants weigh

\footnotetext{
${ }^{3}$ For the purpose of our empirical analysis below, the foreign economy can be thought of as the rest of the world.
} 
their expected profits against the fixed costs. Free entry implies

$$
\begin{aligned}
f_{E} W_{i} & =\int_{\phi_{D}}\left(E_{i}^{H}\left(P_{i}^{H}\right)^{\sigma-1} \zeta\left(\frac{W_{i}}{\phi}\right)^{1-\sigma}-f_{D} W_{i}\right) d G(\phi) \\
& +\int_{\phi_{X}}\left(\tau^{1-\sigma} E_{i}^{F}\left(P_{i}^{F}\right)^{\sigma-1} \zeta\left(\frac{W_{i}}{\phi}\right)^{1-\sigma}-f_{X} W_{i}\right) d G(\phi)
\end{aligned}
$$

In equilibrium, workers are paid their marginal revenue product. Because workers are mobile across firms and industries we have

$w=\frac{\sigma-1}{\sigma}\left(\frac{\phi}{\beta_{i}}\right)^{\frac{\sigma-1}{\sigma}}\left[E_{i}^{H}\left(P_{i}^{H}\right)^{\sigma-1}+\nVdash_{X} \tau^{1-\sigma} E_{i}^{F}\left(P_{i}^{F}\right)^{\sigma-1}\right]^{\frac{1}{\sigma}} l^{\frac{-1}{\sigma}}-\frac{1-\beta_{i}}{\beta_{i}} r$

for all $\phi$ where $\nVdash_{X}$ is an indicator variable that equals one if the firm exports and zero otherwise. The firm subtracts $\frac{1-\beta_{i}}{\beta_{i}} r$ from the left-hand side because every added unit of labor requires the addition of $\frac{1-\beta_{i}}{\beta_{i}}$ units of capital $\left.\right|^{4}$

Let $N_{i}$ represent the number of total potential entrants in industry $i$ (which we consider exogenous). Total domestic sales in industry $i$ are given by:

$$
D_{i}=N_{i} E_{i}^{H}\left(P_{i}^{H}\right)^{\sigma-1} \zeta \sigma W_{i}^{1-\sigma} \int_{\phi_{D i}} \phi^{\sigma-1} d G(\phi)
$$

and total export sales in industry $i$ are give by:

$$
X_{i}=N_{i} E_{i}^{F}\left(P_{i}^{F}\right)^{\sigma-1} \zeta \sigma W_{i}^{1-\sigma} \int_{\phi_{X i}} \phi^{\sigma-1} d G(\phi)
$$

\subsection{Comparative statics}

In this section we demonstrate the impact of a resource windfall on the domestic and export cutoffs, the number of varieties produced, and the con-

\footnotetext{
${ }^{4}$ See Online Appendix Section $[$ A.2 for more details on the derivation of equation (7).
} 
centration of exports. We will assume that $\phi$ is distributed by $G(\phi)=$ $1-\left(\frac{\phi_{\min }}{\phi}\right)^{\theta}$ and that $\theta>20^{5}$. For simplicity, we further assume that $\phi_{\min }=1$. Suppose that the home economy receives a resource windfall and exogenous income increases from $Z_{0}$ to $Z_{1}$. Equation (7) shows that this puts upward pressure on wages. When the increase in $Z$ leads to an increase in $E_{i}$, firms must increase production to keep pace with demand. In order to produce more, firms must increase their stocks of labor. Because the total amount of labor in the economy is fixed, firms must take workers away from others in order to increase their own stocks of labor. This puts upward pressure on wages and results in $w_{1}>w_{0}$.

\subsubsection{Export productivity cutoffs and number of varieties}

Let a hat $\hat{\imath}$ over a variable represent a percentage change. As in Ostenstad and Vermeulen (2016), totally differentiating (5) gives:

$$
\hat{\phi}_{X i}=\frac{\sigma}{\sigma-1} \hat{W}_{i}
$$

A visualization of changes for $\hat{\phi}_{X i}$ is provided in Figure 1. The results show that the export productivity cutoff increases after wages increase. In other words, following a resource windfall, more firms -which implies different varieties in this case- exit the export market, resulting in more concentrated export basket in terms of different varieties. The number of varieties in

\footnotetext{
${ }^{5}$ This assumption comes to play when deriving the concentration index below. Without it, the integral used in the derivation is not defined.
} 
industry $i$ sold abroad can be written as:

$$
N_{i}\left[1-G\left(\phi_{X i}\right)\right]
$$

Thus, because the export cutoff increases after a windfall, the product variety of exports decreases $\sqrt[6]{6}$

[Figure 1 about here.]

\subsubsection{Export concentration}

In this section we derive the The Herfindahl-Hirschman concentration index (HHI) for exported varieties, which will be a useful guide for the empirical part later on.

Exports for a type- $\phi$ firm in industry $i$ are given by:

$$
q_{x i}(\phi)=\tau^{1-\sigma} E_{i}^{F}\left(P_{i}^{F}\right)^{\sigma-1}\left(\frac{\sigma}{\sigma-1}\right)^{-\sigma} W_{i}^{-\sigma} \phi^{\sigma}
$$

Thus, total exports in an industry can be written as:

$$
Q_{X i}=N_{i} \tau^{1-\sigma} E_{i}^{F}\left(P_{i}^{F}\right)^{\sigma-1}\left(\frac{\sigma}{\sigma-1}\right)^{-\sigma} W_{i}^{-\sigma} \int_{\phi_{X i}} \phi^{\sigma} d G(\phi) .
$$

Total exports in the economy are:

$$
Q_{X}=Q_{X 1}+Q_{X 2}
$$

\footnotetext{
${ }^{6}$ See Online Appendix Section A.1 for a discussion on the domestic productivity cutoff.
} 
which can be rewritten as:

$$
Q_{X}=\frac{N_{1} E_{1}^{F}\left(P_{1}^{F}\right)^{\sigma-1} W_{1}^{-\sigma} \phi_{X 1}^{\sigma-\theta}+N_{2} E_{2}^{F}\left(P_{2}^{F}\right)^{\sigma-1} W_{2}^{-\sigma} \phi_{X 2}^{\sigma-\theta}}{N_{i} E_{i}^{F}\left(P_{i}^{F}\right)^{\sigma-1} W_{i}^{-\sigma} \phi_{X i}^{\sigma-\theta}} Q_{X i}
$$

for $i \in\{1,2\}$. The market share of a firm with productivity $\phi$ in industry $i$ is:

$$
\begin{aligned}
\frac{q_{x i}(\phi)}{Q_{X}} & =\Gamma_{i} \frac{q_{x i}(\phi)}{Q_{X i}} \\
& =\Gamma_{i}\left(\frac{\theta-\sigma}{N_{i} \theta}\right) \frac{\phi^{\sigma}}{\phi_{X i}^{\sigma-\theta}}
\end{aligned}
$$

where $\Gamma_{i} \equiv \frac{N_{1} E_{1}^{F}\left(P_{1}^{F}\right)^{\sigma-1} W_{1}^{-\sigma} \phi_{X 1}^{\sigma-\theta}+N_{2} E_{2}^{F}\left(P_{2}^{F}\right)^{\sigma-1} W_{2}^{-\sigma} \phi_{X 2}^{\sigma-\theta}}{N_{i} E_{i}^{F}\left(P_{i}^{F}\right)^{\sigma-1} W_{i}^{-\sigma} \phi_{X i}^{\sigma-\theta}}$. The HHI for exports is the sum of squared export market shares which is given by:

$H H I_{X}=\Gamma_{1}^{2}\left(\frac{\theta-\sigma}{N_{1} \theta}\right)^{2} \phi_{X 1}^{2(\theta-\sigma)} N_{1} \int_{\phi_{X 1}} \phi^{2 \sigma} d G(\sigma)+\Gamma_{2}^{2}\left(\frac{\theta-\sigma}{N_{2} \theta}\right)^{2} \phi_{X 2}^{2(\theta-\sigma)} N_{2} \int_{\phi_{X 2}} \phi^{2 \sigma} d G(\sigma)$.

This can be rewritten as:

$$
H H I_{X}=\xi\left(\Gamma_{1}^{2} \frac{\phi_{X 1}^{\theta}}{N_{1}}+\Gamma_{2}^{2} \frac{\phi_{X 2}^{\theta}}{N_{2}}\right)
$$

where $\xi \equiv\left(\frac{\theta-\sigma}{\sqrt{\theta(\theta-2 \sigma)}}\right)^{2}$. Because $\phi_{X 1}$ and $\phi_{X 2}$ are related by:

$$
\phi_{X 2}=\left(\frac{E_{1}^{F}}{E_{2}^{F}}\right)^{\frac{1}{\sigma-1}}\left(\frac{P_{1}^{F}}{P_{2}^{F}}\right)\left(\frac{W_{2}}{W_{1}}\right)^{\frac{\sigma}{\sigma-1}} \phi_{X 1}
$$

the weights $\Gamma_{i}$ are not changing in either $\phi_{X i}$. This implies that $H H I_{X}$ is 
increasing in the cutoffs $[7$

A resource windfall leads to an increase in the export productivity cutoff. As a result, a resource windfall reduces the size of the export sector, which in turn reduces the export product variety. Consistently, resource windfall leads to a more concentrated export basket, which in this framework we measured using the Herfindahl-Hirschman Index. Furthermore, because $\beta_{1}>\beta_{2}$, we have that $\hat{W}_{1}>\hat{W}_{2}$. Therefore, as the productivity cutoff of the laborintensive sector increases more than that of the capital-intensive one, the relative share of the latter within the non-resource export basket rises. After the windfall, the non-resource export basket is more concentrated in general, and leans more towards capital-intensive goods.

\section{Data and stylized facts}

The main source of data for the rest of the paper is global export data, which comes from UN COMTRADE database with corrections made by Hausmann et al. (2011). It includes exports from all countries to the rest of the world, classified using the Standard Industry Trade Classification (SITC), revision 2, at the four-digit level, over 1984 to 2010. In order to classify products as resource or non-resource, we rely on the definitions of Primary Products provided by Lall $(2000) 8^{8}$

When testing for the impacts of natural resources on non-resource export baskets we control for total exports (to control for scale) as well as income per

\footnotetext{
${ }^{7}$ See Online Appendix Section $[$ A.3 for more details on the derivation of export HHI.

${ }^{8}$ See Table A1 in Appendix Section B for a list of all three-digit categories considered as primary products. Our results are robust to expanding the definition of natural resources to all resource-based products described there.
} 
capita, the latter derived from the World Development Indicators database (World Bank, 2016). Our base sample includes information for 128 countries and 27 years.

We complement the analysis with two other data sources that will help us to deal with the plausible endogeneity between non-resource export concentration and Dutch Disease. First, we use data from Horn (2010) on oil and gas fields discoveries across the globe which include events happening during the period of the study. This dataset has information on the location and time of all gas or oil field discoveries, including the volume of oil or gas discovered measured in estimated million barrels of oil equivalent. Figure 2 presents the geographic distribution of the discoveries throughout all the years in the original database. When merging it with our countryyear dataset, we end up with information on 190 discoveries in 43 countries between 1984 and 2010 9

[Figure 2 about here.]

Second, we include data on commodity prices for 22 different commodities, which are: Aluminum, Bananas, Beef Meat, Chicken Meat, Coal, Cocoa, Coffee, Copper, Cotton, Crude Oil, Gold, Liquified Natural Gas, Oranges, Rice, Rubber, Sheep Meat, Shrimp, Soybean, Tea, Tobacco, Wheat and Zinc. We assign a commodity price to every country in every year by matching the commodity name to the name of the largest natural resource 4-digit export reported in the trade data using SITC categorization. We normalize the

\footnotetext{
${ }^{9}$ Recently, Arezki et al. (2017) used this dataset to investigate the macroeconomic adjustment effects following a large oil and gas discovery.
} 
price of each commodity to be equal to 100 in 2010. This data comes from the Global Economic Monitor database by the World Bank (2017).

Given that our focus is on understanding the relationship between Dutch Disease and non-resource export concentration, we compute for each country and year four measures of export concentration widely used in the literature (e.g. Koren and Tenreyro, 2007; Cadot et al., 2011; Imbs and Wacziarg, 2003): the Herfindahl-Hirschman index (HHI), the Gini coefficient, the lognumber of non-resource product exported with value above zero, and the Theil index 10 The Theil index can be decomposed into a within and between component. In the context of export concentration, the Theil-within index refers to changes in export shares of existing industries, while the Theilbetween index refers to appearance and disappearance of export lines. We often present results using each of those components of the Theil index as the dependent variable. Note that in order to compute concentration we exclude natural resource products from the export basket of countries prior to the calculation. Figure 3 documents the existence of a consistent, positive relationship between the share of natural resources in exports and the degree of concentration of the non-resource export basket as measured by these four indicators, using cross-country data for the year 2010 11

[Figure 3 about here.]

Table 1 provides a summary of descriptive statistics for variables at the

\footnotetext{
${ }^{10}$ See Appendix Section $D$ for details on the formulas and construction of these indexes.

${ }^{11}$ To prepare the charts we have excluded all countries where natural resources represent less $\tan 5 \%$ of total exports. The analysis that follows has not been truncated in any way. The slope in the case of the fourth indicator (non-resource export lines open) is negative, indicating that as the share of natural resources in the export basket increases, the number of non-resource products exported tend to decrease (i.e., concentration is increased).
} 
country level, in separate panels comprising all country-years in our sample (Panel A), Non-OECD (Panel B), and OECD countries (Panel C). While natural resources represent on average $48.2 \%$ of non-OECD export baskets throughout the period 1985-2010, they accounted for $20.3 \%$ of OECD exports. At the same time, OECD countries tend to have much less concentrated non-resource export baskets, and their statistics are less dispersed than those of non-OECD countries.

[Table 1 about here.]

\section{Natural resource exports and non-resource ex- port concentration}

This section aims at empirically exploring one of the main predictions of the theoretical model introduced above: non-resource export concentration increases following a Dutch disease episode 12 We begin by estimating if countries with larger shares of natural resource exports (e.g., those that are more prone to suffer from Dutch disease) tend to have a more concentrated non-resource export baskets. To do so, we estimate the following specification:

$$
C I_{i t}=\beta N a t \text { Res }_{i t}+\operatorname{lgdppc}_{i t}+\text { ltotexp }_{i t}+\delta_{t}+\varepsilon_{i t}
$$

\footnotetext{
${ }^{12}$ Our data finds suggestive evidence that, indeed, the tradable sector as a whole tends to be smaller in size in countries more prone to suffer from Dutch disease, consistent with the main proposition of Corden and Neary (1982), but the results are not robust to different methodologies. However, the focus of this paper is on the impact of Dutch disease on the composition of the tradable sector, and not on its aggregate size.
} 
Where in each case the dependent variable is a non-resource export concentration indexes described above (denoted by $C I$ ), computed for country $i$ in period $t$. The specification includes in the right hand side our variable of interest, the percentage of natural resources in the export basket of countries (NatResit), as well as income per capita (in logs, denoted by $l g d p p c_{i t}$ ) and total exports (in logs, denoted by ltotexp $_{i t}$ ). Controlling for income per capita allows us to account for the fact that richer countries tend to be more diversified (e.g., Imbs and Wacziarg, 2003; Hausmann et al., 2007; Hidalgo et al., 2007; Koren and Tenreyro, 2007; Cadot et al., 2011). Controlling for total exports is useful for two reasons: first, concentration of the export basket might be related to the size of the export basket; second, the Dutch disease literature emphasizes that following a resource windfall we would expect the tradable sector to shrink, and thus, by controlling for the size of the export basket we focus on the relationship between natural resource exports and export concentration beyond the aggregate size of the export basket. We also include a full set of year fixed effects $\delta_{t}$, to control for yearly shocks common to all countries. Given that yearly changes in the share of natural resources in the export basket of a single country are relatively small, we refrain from adding country fixed effects to this specification. As $89.1 \%$ of the total variance of the share of natural resources in exports comes from differences between countries, our reported effects are the mirror of crosscountry variations, as opposed to within country variation ${ }^{13}$ This approach raises concerns on the validity of our inference, a feature we deal with below.

\footnotetext{
${ }^{13} \mathrm{~A}$ standard variance decomposition analysis reported in Online Appendix Section A2 shows that only $10.9 \%$ of the total variation registered in the share of natural resources on export baskets comes from the within component (differences within countries).
} 
The estimations for specification (15) are reported in Table 2 for all countries (columns 1 to 3 ), for OECD countries (column 4 to 6) and for non-OECD countries (columns 7 to 9 ). Our primary interest is in the value of the coefficient $\beta$. When looking at all countries (columns 1 to 3 ), the estimator for $\beta$ is positive and highly significant in columns 1 and 2 (where the dependent variable are concentration indexes), and negative and statistically significant in column 3 (where the dependent variable is number of products), indicating a positive relationship between the share of natural resources in exports and the concentration of the non-resource export basket for the average country. The economic significance of the estimator is also remarkable: countries with 30 percentage points (pp.) in the share of natural resources in total exports above average (roughly one standard deviation) tend to have a higher HHI by 0.06 points, which corresponds to a $44 \%$ increase based on the mean HHI value in the sample. The same increase is associated with a higher Gini coefficient by 0.024 points, which corresponds to a $17 \%$ increase (based on the average Gini coefficient in the sample). In terms of number of varieties or products (column 3), an increase of 30pp. in the share of natural resources in total exports is associated with about $10 \%$ fewer items in their non-resource export basket. Across all different measures, it is quite consistent that a larger export share of natural resources by one standard deviations is roughly associated with higher export concentration by about a third of a standard deviation (e.g., 0.06 for HHI where the sample's standard deviation is $0.18,0.024$ points for the Gini where the sample's standard deviation is 0.081 ; and -0.11 for the log-number of products where the sample's standard deviation is 0.433$)$. 
Columns 4-6 and 7-9 report the estimates when we split the sample into developed (OECD) and developing (non-OECD) countries, respectively. We find that the results are predominantly driven by non-OECD countries. The relationship between natural resources and the degree of concentration of the non-resource export basket is much weaker in the case of OECD economies, with coefficients that have the expected sign but lower levels of significance or no significance at all. The estimates for non-OECD countries are similar in size than those from sample using all countries.

[Table 2 about here.]

The theoretical framework above does not distinguish between changes in concentration at the extensive or intensive margin. That is, whether concentration occurs because the closing of export lines or products (extensive) or because export value concentrates on fewer products among all the existing lines (intensive) ${ }^{14}$ We, however, can exploit this empirically using the Theil index, which as explained above, can be decomposed into a within (intensive margin) and between (extensive margin) component 15 Table 3 uses the Theil index as the dependent variable in its overall form, and using both its between and within component. Columns 1-3 show results for all countries, columns 4-6 show results for OECD countries and columns 7-9 show results for non-OECD economies. Overall, the estimates suggest that countries with 30pp. above average in the share of natural resources in total exports have

\footnotetext{
${ }^{14}$ In fact, in the theoretical framework, if we interpret each variety as one line, the concentration that occurs following a windfall is completely at the extensive margin, as fewer varieties are exported following the increase in salaries.

15 Cadot et al. (2011) uses this index to show that most of the changes in concentration that countries experience throughout their different stages of development are in the extensive margin.
} 
a higher higher (overall) Theil by about 0.45 points (a $27 \%$ increase based on mean value). Also in this case, consistently with the results above, a one standard deviation increase in the export share of natural resources explains about a third of the sample's standard deviation increase in the Theil index. In columns 2 and 3 we see that, for the most part, a higher share of natural resources in the export basket is associated with a larger concentration as measured by the within component, as opposed to the between component. In particular, the results suggest that about 75 percent of the changes in export concentration are driven by the enlargement of exports shares of already existing export products (Column 2). The remaining 25 percent of changes in export concentration as explained by a larger share of natural resource exports can be explained by non-resource export lines disappearing from the export basket (Column 3) 16

The results reported in columns 7-9 in Table 2 are consistent with those of Table 2, as they are mostly driven by developing (non-OECD) countries. The decomposition of the Theil variation for the developing countries does not depart significantly from that of the overall sample: Changes in the relative size of existing products in the non-resource export basket account for $69 \%$ of the Theil increase, whereas reductions in the number of products exported accounts for $31 \%$.

[Table 3 about here.]

Overall, these results reveal a consistent, significant and positive relationship between the share of natural resources in exports and the concentration

\footnotetext{
${ }^{16}$ Note that the estimates in Columns 2 and 3 sum up to the estimate in Column 1.
} 
of the non-resource export basket. This implies that countries more prone to suffer from Dutch disease - given their high shares of natural resources in their export baskets - typically have less diversified non-resource export baskets. Yet, the results are no more than cross-country partial correlations, and therefore the estimates might be biased. Next, we deal with endogeneity concerns.

\subsection{Dealing with endogeneity: field discoveries and commod- ity prices as instrumental variables}

As mentioned above, the results presented so far raise questions of inference as we are only estimating cross-country differences and thus are prone to omitted variable bias. We deal with this issue by employing two pieces of information to help us better identify the relationship under consideration: discoveries of oil and gas fields and yearly commodity prices. First, we employ these two variables -separately- to instrument for the share of natural resources in total exports of countries, using the same specification described above.

Table 4 presents results of 2SLS estimation for specification (15) instrumenting the variable of interest $\left(\right.$ NatRes $\left._{i t}\right)$ with a binary variable that takes the value of 1 if country $i$ discovered an oil or gas field in period $t$. The dataset covers 190 discoveries in 43 countries between 1984 and 2010. An oil and gas discovery is one of the typical textbook examples of a Dutch Disease: a new oil or gas field is discovered, and in a short period of time it translates into a larger exports of natural resources. The exclusion restriction assumption for this instrument to be valid is that discoveries are exogenous to the composi- 
tion of the export basket of the non-resource sector, other than through the changes it generates on the natural resource sector itself. This is a reasonable assumption, unless there are reasons to believe that the discovery itself is achieved using limited resources such as capital and labor, which could have an impact on the composition of the non-resource export basket prior to the discovery. Note that we still do not use country-fixed effects, but if the exclusion restriction is valid, this should not pose a problem to inference.

[Table 4 about here.]

The results in Table 4 presents estimates using all countries in the sample for all concentration indexes as dependent variables, and the point estimates are similar in magnitude than those in Tables 2 and 3 . The table also reports in its last line the Kleibergen-Paap F statistic (denoted "KP F Stat"), which measures the strength of the first stage of the instrument in explaining the main endogenous variable, which in our case is the share of natural resources in the country's export basket ${ }^{17}$ The first stage $\mathrm{F}$ statistic is close to 20 , and therefore we can rule out having a weak instrument problem 18 It is important to notice that these estimates are considered to be the Local Average Treatment Effect (LATE), and the correct way to interpret them is that changes in the share of natural resources in the export basket of a country induced by the discovery of gas and oil fields, explains larger export concentration in the non-resource sector. Interestingly enough, despite the estimators being LATE, we can't reject the hypothesis that any of the esti-

\footnotetext{
${ }^{17}$ The Kleibergen-Paap F statistic, as opposed to the Cragg-Donald statistic, is used when not assuming i.i.d. errors.

${ }^{18}$ Results for the first stage regression are available in Online Appendix Section E.1.
} 
mated coefficients of interest are statistically different than when using the simple cross-country OLS estimator 19

To complement our efforts to better identify the relationship under consideration, we also present results in Table 5 using the same specification but with a different of instrument: world commodity prices. In order to improve fit in the first stage we use both the price of the commodity that corresponds to the country's largest 4-digit export together with the share of that 4-digit export within the total exports of natural resources. As explained above, in order to match commodity prices from the World Bank's Global Economic Monitor database, we perform an algorithm that matches the name of the commodity used in the prices database to the name of the largest natural resource 4-digit export reported in the trade data. Naturally, the price of the commodity will explain changes in the share of natural resources in the total export basket as long as this 4-digit commodity is large enough within that set of goods, and this is crucial for the strength of our instrument measured in the first stage. For example, the price of oil will perform very well explaining changes in the natural resource share of Saudi Arabia's export basket given that the 4-digit crude oil export category represents a very large share of overall natural resource exports. In cases where the exports of natural resources is much more diversified across different (unrelated) 4-digit commodities, the price of the largest 4-digit commodity won't be able to explain much of our endogenous variable (the total share of natural resources in the export basket). Thus, we use both the price of

\footnotetext{
${ }^{19}$ Tables A5 and A6 in Appendix F.1 replicates Table 4 for OECD and non-OECD economies, respectively, and show that consistently with the results above, most of the effect is driven by developing countries.
} 
the commodity and the share of the matching 4-digit commodity in the total exports of natural resources, which is a number between 0 and 120 In this case, to be able to interpret our results as causal, our exclusion restriction assumption must be that commodity prices of a country's largest natural resource (4-digit) export product together with weight of that product in the overall exports of natural resources are exogenous to countries' concentration of their non-resource tradable sector (besides the effect it has through the rise in the share of natural resources in the export basket of countries). We think this is a reasonable assumption to make, particularly for the vast majority of countries in the sample that can be characterized as small open economies 21

[Table 5 about here.]

The results in Table 5 are consistent with what we have discussed so far, with the only difference being that the magnitudes in most cases (besides the Gini) are almost double in size. Again, we cannot reject the hypothesis that the estimates across the different estimation methods are statistically the same given the estimated standard errors 22

\footnotetext{
${ }^{20}$ This would also work if we simply weight the price of the commodity by that share, but in this case the first stage is not as strong, so we rather use the two variables as two instruments for the same endogenous variable.

${ }^{21}$ Results for the first stage regression are available in Online Appendix Section E.2.

${ }^{22}$ Tables A7 and A8 in Appendix F.2 replicates Table 5 for OECD and non-OECD economies, respectively, and show that consistently with the results above, most of the effect is driven by developing countries.
} 


\subsection{Dealing with endogeneity: unusual commodity price spikes in a difference-in-differences setting}

As noted above, when using the previous specification, the variation left in share of natural resources in country's export basket -our variable of interest- is very little after including country fixed effects, and thus it is impossible to produce a within-country estimator. However, with the help of one of the variables used as instruments in the previous subsection we could exploit episodes where there is enough within-country variation in the main independent variable in order to produce a within-country estimator. To do so, we limit the sample to periods before and after an unusual spike in commodity prices, and estimate the relationship of interest using a differencein-differences estimator, allowing for country fixed-effects. ${ }^{23}$

The specification we estimate, thus, is the following:

$$
C I_{i t}=\text { Btreat }_{i} \times \text { after }_{t}+\text { lgdppc }_{i t}+\text { ltotexp }_{i t}+\eta_{i}+\delta_{t}+\varepsilon_{i t}
$$

Where treat $_{i}=$ NatRes $_{i, t}-$ NatRes $_{i, t-1}$. That is, the treatment used for the difference-in-differences estimator is a continuous variable that measures the difference in the share of natural resources in country $i$ 's export basket before (year $t=-1$ ) and after (year $t=1$ ) the spike in the prices of the

\footnotetext{
${ }^{23}$ We also did the same exercise using periods before and after a discovery of a gas or oil field, but as opposed to prices, discoveries do not necessarily affect the total volume of natural resources exported within a short period of time. However, the results using variation around discoveries are qualitatively similar, though the sample is significantly reduced (only about 80 observations) resulting in point estimates that have the "correct" sign but that are statistically significant only for two of the concentration measures used as dependent variables. These results are available upon request.
} 
commodity relevant for that country in year $t=0$. after $_{t}$ is a dummy variable which takes the value 1 for the observations after the event (year $t=$ 1 ) and the value 0 for the observations before the event (year $t=-1$ ). The control variables are the same as in the previous specification, but this time we include $\eta_{i}$ which represents country fixed effects. Under this specification, if the estimation of $\beta$ is positive it means that a larger increase in share of natural resources in the country's export basket (due to a price spike) is associated with higher concentration of the non-resource export basket. If we assume that the sudden price spike of commodities is exogenous to a country around the time of the event, then we could interpret this estimator as causal. This seems like a reasonable assumption, particularly for developing and/or small countries, which are the ones driving the results we have seen so far.

Table 6 presents all the episodes in the dataset that we define as an unusual commodity price spike, detailing the commodity for which and the year when the spike happened. To define an episode of unusual price spike for each commodity we first compute the standard deviation of the price for such commodity during the years of the sample (denoted by $\sigma_{P}$ ). Then, we identify those episodes in which the change in the nominal price from one year to another is equal or higher than one standard deviation. Using this definition we end up with 39 episodes of unusual price spikes listed in the table.

[Table 6 about here.]

Using this information, we then limit our sample to country-year observations that include one year before and one year after a price spike based on 
the main commodity the country exports. A country might appear several times if there is more than one price spike during the sample period of its main commodity, or might not be in the sample at all if its main commodity did not experience a price spike in the terms we defined above. Thus, we end up with a sample of 186 observations, with 139 being developing and 47 being developed countries. The summary statistics for such sample are presented in Table 7. Interestingly enough, when comparing the average values and standard deviations of the concentration indices, the dependent variables, to the ones that include the overall sample (presented in Table 1), one notices that they are quite similar. The one variable that is absent in this table as compared to the overall sample summary statistics table is the level of the share of natural resources in the country's export basket. In this table, instead, we present the difference in that share between the year of the spike $(t=0)$ and a the following year $(t=1)$, which is our treatment variable in this difference-in-differences approach.

[Table 7 about here.]

The results for the estimation of specification (16) using all countries are presented in Table 8. Despite the different methodology, these new results are consistent with the ones we have presented so far. For instance, an increase in the share of natural resources in a country's export basket by one standard deviation after a spike in commodity prices -which corresponds to the value 0.049 according to Table 7 is associated with higher concentration as measured by the HHI by 0.059 points. Based on the average values in the sample, this corresponds to an increase of about $60 \%$. When it comes 
to the Gini coefficient, a similar increase in the treatment variable results in higher export concentration of the non-resource sector by 0.049 points, which corresponds to an increase of $3.8 \%$ based on the sample's average. The third column, which uses the log-number of products as the dependent variable has the same sign as the previous results, but the result is not statistically significant. However, an increase of one standard deviation in the treatment variable corresponds to a decrease in number of products of $3 \%$. When it comes to the Theil index, the analogous calculation results in an index higher by about $16.6 \%$. Like the results presented so far, this new estimator suggests that most of the changes in the Theil index, following an increase in the share of natural resources in a country's export basket, are in the within, and not the between, component ${ }^{24}$ Again, using this sample we find consistent, though somewhat larger, results as with the previous methodology when translated into standard deviations. All in all, a one standard deviation increase in the treatment variable explains an increase of about one half of the sample's standard deviation for each one of the different concentration indexes (Columns 1 to 4 ).

\section{[Table 8 about here.]}

All in all, throughout a number of different methodologies, we have shown consistent results that support the main prediction of the theoretical framework presented in Section 2. That is, experiencing an increase in the value of natural resource exports relative to their overall export basket (due to an unusual rise in the price of commodities or the discovery of oil or gas fields,

\footnotetext{
${ }^{24}$ Given the small sample we do not produce separate results for developed and developing countries using this methodology.
} 
for example) would result in a more concentrated non-resource export basket. Note that our result is different from the main prediction of the Dutch disease, which predicts a smaller overall tradable non-resource sector following the increase in natural resource exports. Our result, in fact, goes one step beyond and focuses on changes in the composition within the tradable non-resource export basket, by finding that it becomes more concentrated.

\section{Concentration toward capital-intensive products}

In this section of the paper we turn to dig into the type of products that are more likely to thrive in the export basket of a country that is more prone to Dutch disease episodes. In particular, the theoretical framework above (see Section 2.4 shows that in the event of a resource windfall, the resulting higher concentration of the export basket will be less pronounced among the capital-intensive sector. The intuition for this in the model is simple: given that the price of capital is considered fixed, an increase in local wages following a resource windfall would put higher pressure on the costs of labor-intensive goods as compared to capital-intensive goods. In that sense, the number of products or varieties will decrease less in the capital-intensive sector than in the labor-intensive one. As a result, the larger concentration of the export basket following a Dutch disease episode

would be biased towards capital-intensive goods. This, in fact, is something we can test for empirically.

To do so, we increase the resolution of our analysis and look at a countryproduct-year level dataset. Using the same data sources we construct a dis- 
aggregated dataset for 128 countries, 580 non-resource export products and 27 years. Similarly to before, resource export products are defined as those classified by Lall (2000) as primary products (listed in Table A1 in Online Appendix Section B]. In order to measure the capital intensity for each of these products, we use merge data from the NBER productivity dataset (Becker et al., 2013), and use the share of capital in the total value added of the industry manufacturing that product (similarly to Nunn, 2007) 25 Capital intensity data is measured year-by-year, but we instead compute the average capital intensity for every product throughout all the years in the sample, just to reduce possible endogeneity concerns of certain products becoming more capital-intensive as a response to changes in global wage levels (even though we control for product-year fixed effects) ${ }^{26}$ Note that capitalintensity is computed such that it is a "mirror image" for labor intensity, thus a capital-intensive product is a non labor-intensive one.

In order to test our hypothesis using this setting, we estimate the explanatory power of variations in the natural resource intensity of a country interacted with the capital intensity of a product over the relative size of that product in the export basket. To do so we estimate the following specification:

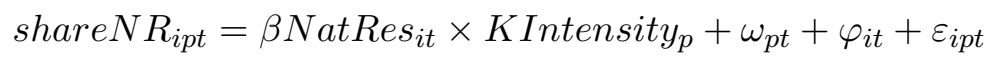

\footnotetext{
${ }^{25}$ We follow the methodology suggested by Cunat and Melitz $(2012)$ in their footnote 24 to create a concordance table from NAICS classification to SITC. We use that concordance table to define capital intensity for each SITC 4 digit industries. We thank Muhammed Yildirim for guidance in this task.

${ }^{26}$ Our results are robust to using the time-variant version of the variable.
} 
where share $N R_{i p t}$ in the share of product $p$ in the non-resource export basket of country $i$ in year $t$; NatRes $i t$ is the share of natural resources in the export basket of of country $i$ in year $t$; KIntensity is a product-level variable measuring capital intensity; $\omega_{p t}$ are product-year fixed effects and $\varphi_{i t}$ are country-year fixed effects. Note that by including country-year fixed effects we control for all factors that vary at the country-year level such as macro variables; as well as those that are constant across time within countries such as geography. Also, by including product-year fixed effects we control for global variations at the product level, such as changes in global demand, common technology upgrading, etc. By including country-year fixed effects we also make sure that we are exploiting a within-country phenomenon, as we estimate how each product responds to changes in the share of natural resources in the export basket of the country. Because of this set of fixed effects it is not necessary to include the interaction terms separately, as they would drop because of perfect multicollinearity. In particular, a positive estimator for $\beta$ suggests that in countries more prone to Dutch disease, the share in exports of capital-intensive sectors increase relative to the share of labor-intensive ones 27

Table 9 presents summary statistics for the main variables used in this exercise. Our sample contains about 1.88 million observations, which correspond to country-product-year combinations. The average share of each non-resource export product in the overall non-resource export basket in the sample is 0.2 percent, with values that go from 0 to 99.4 percent. We include

\footnotetext{
${ }^{27}$ Online Appendix Section $\mathrm{G}$ shows that our results are robust to using a more liberal specification for the non-resource products used to populate the sample, which would exclude all those products classified by Lall (2000) as "resource-based" products.
} 
those country-product-year combination where the share is zero in order to maintain a balanced panel, though our results are robust to excluding those observations. The average share of natural resources in the country's export basket is 43.4 percent, and the average capital intensity of exports in the sample is 0.739 .

[Table 9 about here.]

Table 10 reports the estimates of specification 17) for all countries (Column 1), OECD countries (Column 2) and non-OECD countries (Column 3). using each of the product characteristics. The estimator for $\beta$ is positive and significant in all cases, implying that an increase in the share of natural resources in a country's export basket is associated with a larger share of capital-intensive non-resource products in the non-resource export basket, consistently with the above theoretical framework would predict. We do not see that any particular group of countries (developed or developing) are driving these results.

[Table 10 about here.]

There are other intuitive reasons behind these results that go beyond the scope of the theoretical model we have introduced. For instance, following a resource windfall, some capital-intensive industries could benefit from the real exchange rate appreciation archetypal of episodes of Dutch disease (e.g., Krugman, 1987; Lee, 1995; Calvo et al., 1996; Chinn and Prasad, 2000). This in particular is true in developing countries, that tend to be net importers of capital. 
In this sense, one open question that remains is: if some capital-intensive products could experience growth during a Dutch disease episode, then if we start in a corner solution in where the country under consideration exports only labor-intensive goods, then this country should first experience some diversification. Is that the case? To test for this, we estimate the following specification:

$$
\begin{aligned}
C I_{i t} & =\beta_{l} \text { NatRes }_{i t} \times \text { Kcontent }_{i t}+\beta_{q} \text { NatRes }_{i t} \times \text { Kcontent }_{i t}^{2} \\
& + \text { lgdppc }_{i t}+\text { ltotexp }_{i t}+\eta_{i}+\delta_{t}+\varepsilon_{i t}
\end{aligned}
$$

Where the new variable with respect to Specification $[15)$ is Kcontent ${ }_{i t}$, which is the capital content in the export basket of each country $i$ in the year t. It corresponds to the sum of the capital intensity of each (non-resource) product in the export basket of each country weighted by the share of that product in the overall (non-resource) export basket, and thus is always a number between 0 and 1 . The quadratic term is there to estimate whether the concentration of the export basket of a country changes in non-linear ways for countries with higher levels of natural resource exports at with different levels of capital content in their export basket.

Table 11 presents results for the estimation of specification (18). There, Columns 1 and 2 which use an index of concentration on the left hand side, while Column 3 uses an index of diversification. It can be seen that when measuring concentration (diversification) $\beta_{l}$ is estimated to be negative (positive) while $\beta_{q}$ is estimated to be positive (negative), though not statistically 
significant in Column 2 which uses the Gini coefficient. Based on the point estimates, this implies that for very low levels of capital content, the relationship between higher levels of natural resource exports and concentration levels is negative, implying diversification. In other words, if we think of a country with very little to no exports of capital-intensive products to begin with, we should first expect some export diversification towards capitalintensive products, then after certain threshold we would see concentration. Note that in this case we have enough variation to include country fixed effects, and therefore inference is based on within-country variation.

[Table 11 about here.]

These results are represented graphically in Figure 4 using the HHI to measure non-resource export concentration. As can be noted, the positive relation between export concentration and the share of natural resources (kept constant in the graph) is positive for countries with capital content in their export baskets above 0.5. In the sample, however, this number corresponds roughly to the 10th percentile of the observations, and, therefore we see that the overall effect explored above is positive. That is, most countries have a capital content in their export basket that is well above 0.5, and therefore, in reality, the relationship between increases in natural resource exports and non-resource export concentration is strictly positive 28

[Figure 4 about here.]

\footnotetext{
${ }^{28}$ Country-year observations with capital content in their export basket below 0.5 are typically poor countries such as Bolivia, Cameroon, Cuba, Gabon, Mozambique and Malawi, among others.
} 


\section{Conclusions}

We have analyzed the impacts of natural resource exports over the concentration of the non-resource exports basket. We have developed a theoretical framework that explains the dynamics behind this relationship, and presented robust empirical evidence that countries countries with large exports

of natural resources exhibit high levels of non-resource export concentration. Our finding is particularly pervasive in developing countries. Higher nonresource concentration is driven predominantly by changes in the relative size of existing products, as opposed to changes in the number of active export lines.

These findings go beyond the predicament of the existing Dutch disease literature -stating the non-resource tradable sector as a whole will shrink in response to a resource windfall- and inspects the composition of the nonresource export basket. We have gone one step further and looked into the drivers of that higher concentration at the product level. Using productcountry-year data we find that capital-intensive goods tend to have higher shares in the non-resource export basket of resource rich countries. This finding is consistent with our theoretical model, as the resource windfalls puts upward pressure on domestic wages in a context where capital is freely mobile and its price is exogenous, as determined by international markets.

To the extent of our knowledge, this is the first attempt at documenting the impacts of Dutch disease on the concentration of the non-resource export basket, and analyzing what is driving the changes within that basket at the product level. 
We believe the findings of this paper are important for a number of reasons, and have relevant implications for further research. First, they suggest that the order of factors does alter the product: countries where natural resources were found before they were able to achieve some degree of industrialization, might have different growth and diversification trajectories than those where resource discoveries came later. This particular hypothesis is an important part of our future research agenda. Second, the fact that capitalintensive goods tend to gain share within the non-resource export basket at the expense of labor-intensive ones, might have important implications for income inequality in resource rich countries. Third, it opens questions on the role policy could play in dealing with larger export concentration -a condition linked to macroeconomic volatility- following Dutch disease episodes, particularly in small and developing countries highly reliable on foreign demand. 


\section{References}

Arezki, R., V. A. Ramey, and L. Sheng (2017). News shocks in open economies: Evidence from giant oil discoveries. Quarterly Journal of Economics 132(1), 103-155.

Bahar, D., R. Hausmann, and C. A. Hidalgo (2014, jan). Neighbors and the evolution of the comparative advantage of nations: Evidence of international knowledge diffusion? Journal of International Economics 92(1), $111-123$

Bahar, D. and H. Rapoport (2018). Migration, Knowledge Diffusion and the Comparative Advantage of Nations. The Economic Journal.

Bahar, D., E. Stein, R. Wagner, and S. Rosenow (2017). The Birth and Growth of New Export Clusters: which mechanisms drive diversification? Harvard Center for International Development Working Papers Series (86).

Becker, R. A., W. B. Gray, and J. Marvakov (2013). NBER-CES Manufacturing Industry Database: Technical Notes. Technical Report February.

Beine, M., S. Coulombe, and W. N. Vermeulen (2015). Dutch Disease and the Mitigation Effect of Migration: Evidence from Canadian Provinces. Economic Journal 125(589), 1574-1615.

Bernard, A. B., S. J. Redding, and P. K. Schott (2007). Comparative advantage and heterogeneous firms. The Review of Economic Studies 74(1), $31-66$. 
Cadot, O., C. Carrère, and V. Strauss-Kahn (2011, may). Export Diversification: What's behind the Hump? Review of Economics and Statistics 93(2), 590-605.

Calvo, G. A., L. Leiderman, and C. M. Reinhart (1996). Inflows of Capital to Developing Countries in the 1990s. Journal of Economic Perspectives 10(2), 123-139.

Chinn, M. D. and E. S. Prasad (2000). Medium-Term Detemrinants of Current Accounts in Industrial and Developing Countries: An Empirical Exploration. IMF working paper 59(1), 47-76.

Corden, M. and J. P. Neary (1982). Booming Sector and De-Industrialisation in a Small Open Economy. The Economic Journal 92(368), 825-848.

Corden, W. M. (1984). Booming sector and dutch disease economics: survey and consolidation. Oxford Economic Papers 36(3), 359-380.

Cuñat, A. and M. J. Melitz (2012). Volatility, labor market flexibility, and the pattern of comparative advantage. Journal of the European Economic Association 10(2), 225-254.

Hausmann, R., C. A. Hidalgo, S. Bustos, M. Coscia, S. Chung, J. J\’\imenez, A. Simoes, and M. A. Yildirim (2011). The Atlas of Economic Complexity: Mapping Paths to Prosperity. Cambridge, MA.

Hausmann, R., J. Hwang, D. Rodrik, and D. Rodrick (2007). What you export matters. Journal of Economic Growth 11905(1), 1-25. 
Hidalgo, C. A., B. Klinger, A. A.-L. Barabási, and R. Hausmann (2007, jul). The product space conditions the development of nations. Science (New York, N.Y.) 317(5837), 482-7.

Horn, M. K. (2010). Giant oil and gas fields of the world. American Association of Petroleum Geologists Datapages.

Imbs, J. and R. Wacziarg (2003, feb). Stages of Diversification. American Economic Review 93(1), 63-86.

Klinger, B. and D. Lederman (2004). Discovery and Development: An Empirical Exploration of "New" Products. World Bank Policy Research Working Paper 3450, 1-48.

Koren, M. M. M. and S. Tenreyro (2007). Volatility and Development. The Quarterly Journal of Economics 122(1), 243-287.

Krugman, P. (1987, oct). The narrow moving band, the Dutch disease, and the competitive consequences of Mrs. Thatcher. Journal of Development Economics 27(1-2), 41-55.

Lall, S. (2000). The Technological Structure and Performance of Developing Country Manufactured Exports: 1995 to 1998. Oxford Development Studies 28(3), 337-369.

Lee, J.-W. W. (1995, oct). Capital goods imports and long-run growth. Journal of Development Economics 48(1), 91-110.

Melitz, M. J. (2003). The impact of trade on intra-industry reallocations and aggregate industry productivity. Econometrica 71(6), 1695-1725. 
Neary, J. (1982). Real and monetary aspects of the "Dutch disease". UCD Centre for Economic Research Working Paper Series 5.

Nunn, N. (2007). Relationship-Specificity, Incomplete Contracts, and the Pattern of Trade. The Quaterly Journal of Economics 122(May), 569600 .

Ostenstad, G. and W. N. Vermeulen (2016). The Impact of Windfalls : Firm selection, trade and welfare. OxCarre Research Paper (162).

Sachs, J. D. and A. M. Warner (1995). Natural Resource Abundance and Economic Growth. NBER Working Paper Series 3, 54.

Steingress, W. (2015). Specialization patterns in international trade. Banque de France Working papers 542(March).

Theil, H. (1967). Economics and information theory. North Holland Pub. Co. (16), 488 .

Van der Ploeg, F. and A. J. Venables (2013). Absorbing a windfall of foreign exchange: Dutch disease dynamics. Journal of Development Economics 103(1), 229-243.

World Bank (2016). World Development Indicators Online.

World Bank (2017). Global Economic Monitor. 
Figure 1: Change in the export cutoff after a resource windfall

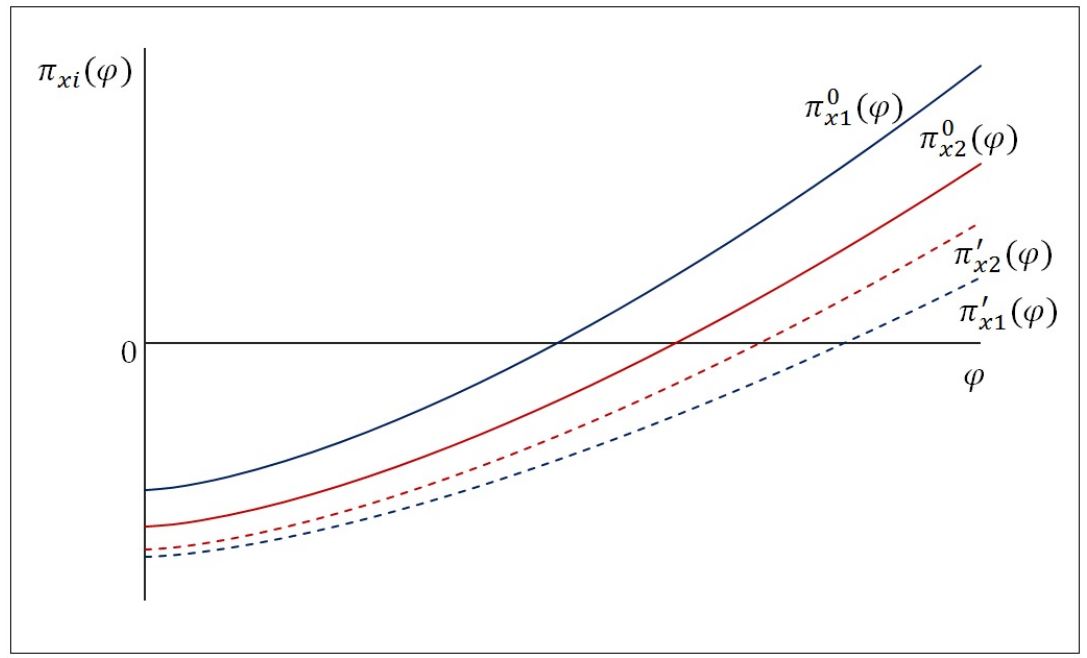

Profits in the export sector $\phi_{d i}(\phi)$ are represented on the vertical axis and the productivity parameter $\phi$ is represented on the horizontal axis. Profits for labor-intensive Industry 1 are represented in blue while profits for capitalintensive Industry 2 are represented in red. The pre-windfall equilibrium is represented with a naught superscript and a solid line while the post-windfall equilibrium is represented with a prime superscript and a dashed line. The fixed costs for both industries increase as a result of the increased wage rate. In addition, the slopes of each profit curve decreases as a result of the increased wage. These changes are larger in magnitude for the labor-intensive industry than for the capital-intensive industry. 
Figure 2: Geographic distribution of oil and gas field discoveries database

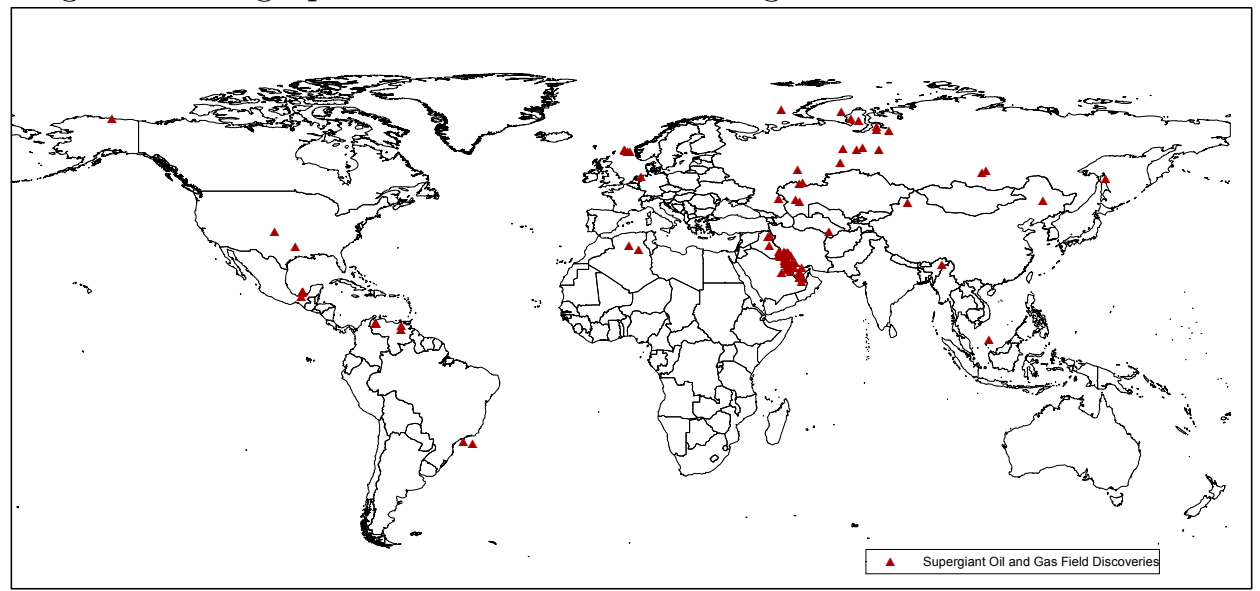

This figure maps the location of all the oil and gas field discoveries in the above mentioned dataset by Horn (2010). 
Figure 3: Non-resource export concentration and natural resource share of exports (2010)
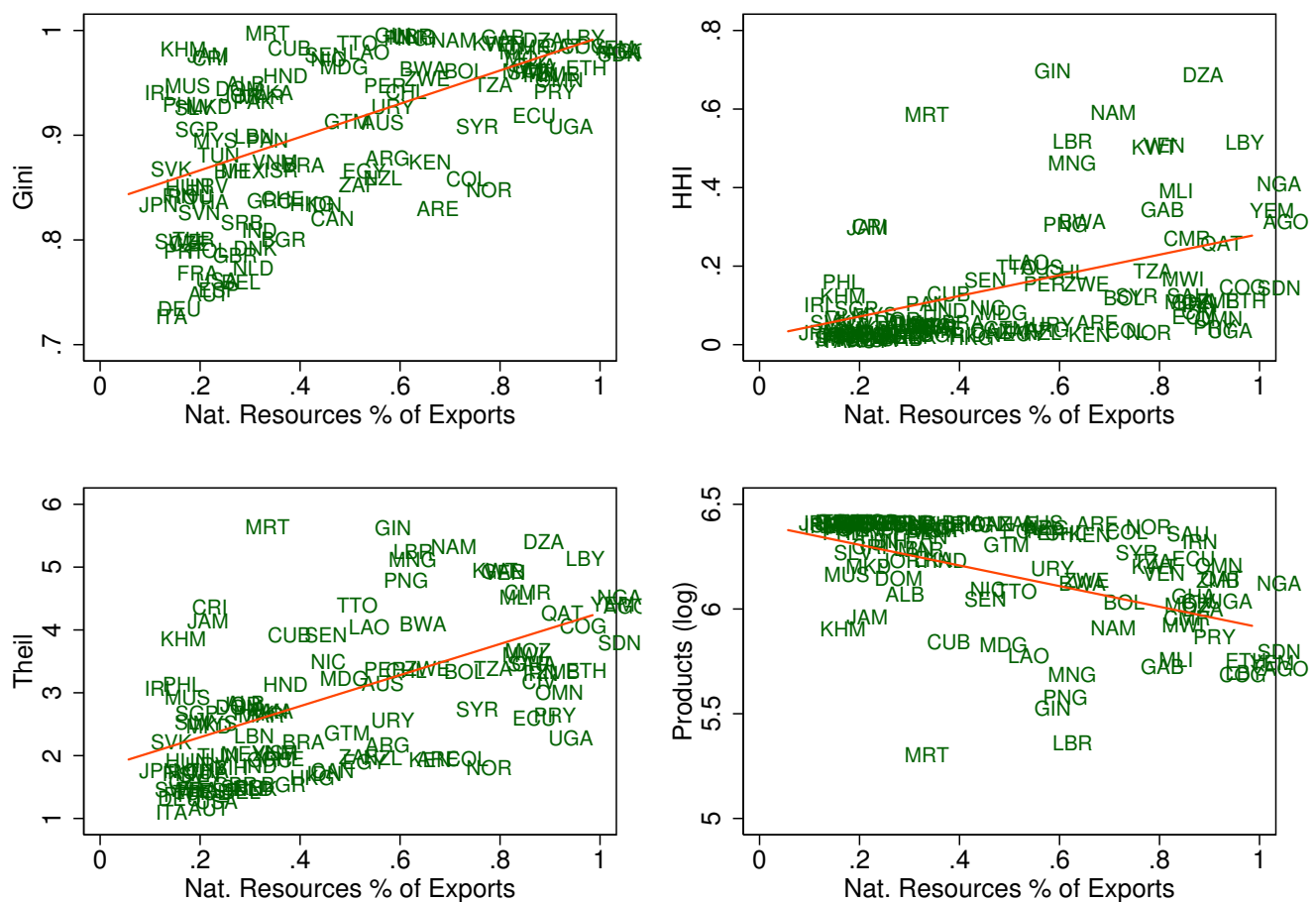

This figure shows four scatterplots using in the vertical axis a measure of concentration and on the horizontal axis the share of natural resources in a country's export basket for the year 2010 . In all figures it can be seen that countries with a higher share of natural resource in their export basket tend to be more concentrated in their non-resource export basket. 
Figure 4: Non-resource export HHI and capital content non-linear relationship

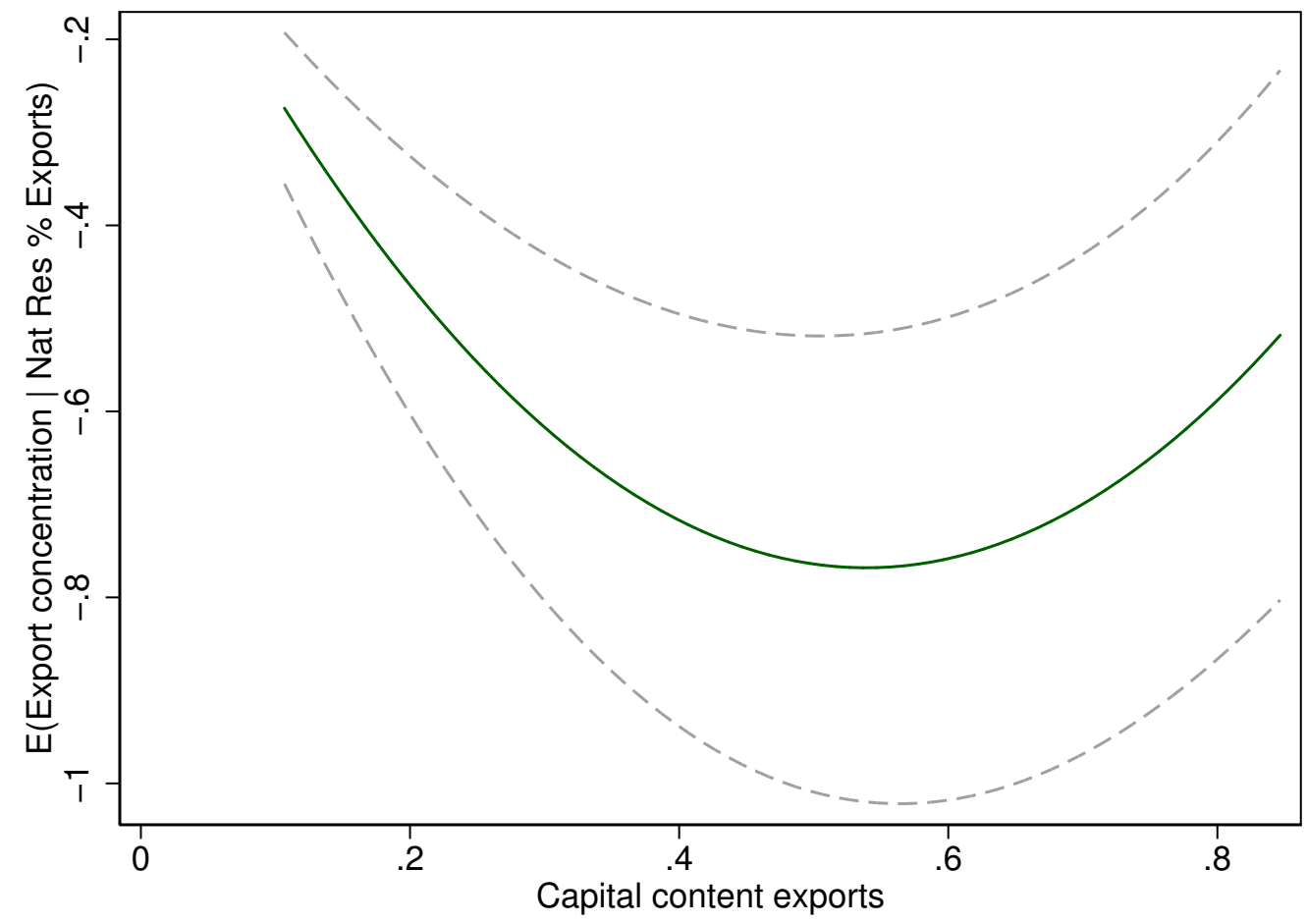

This figure graphs the relationship driving the partial correlation between the export share of natural resources and non-resource concentration based on the initial value of the capital content of a country's export basket. It is based on the estimation of $\beta_{l}+2 \beta_{q} K_{\text {content }}$ it for a given level of NatRes $s_{i t}$ based on specification [18, using HHI as the dependent variable. 
Table 1: Summary statistics at the country-level (1985-2010)

\begin{tabular}{|c|c|c|c|c|c|}
\hline Variable & $\overline{\mathrm{N}}$ & Mean & Std. Dev. & Min & Max \\
\hline \multicolumn{6}{|c|}{ Panel A. All countries } \\
\hline $\mathrm{HHI}$ & 2524 & 0.134 & 0.181 & 0.007 & 0.959 \\
\hline Gini & 2524 & 0.901 & 0.081 & 0.670 & 0.998 \\
\hline Products $(\log )$ & 2524 & 6.067 & 0.433 & 3.714 & 6.426 \\
\hline Theil & 2524 & 2.841 & 1.239 & 0.880 & 6.271 \\
\hline Theil Within & 2524 & 2.480 & 0.952 & 0.859 & 5.358 \\
\hline Theil Between & 2524 & 0.360 & 0.434 & 0.000 & 2.736 \\
\hline NatRes \% e & 2524 & 0.410 & 0.289 & 0.026 & 0.990 \\
\hline Income pcap (log) & 2524 & 9.042 & 1.195 & 4.956 & 11.754 \\
\hline Total exports (log) & 2524 & 22.831 & 2.109 & 17.017 & 28.150 \\
\hline \multicolumn{6}{|c|}{ Panel B. Non-OECD countries } \\
\hline HHI & 1869 & 0.171 & 0.196 & 0.011 & 0.959 \\
\hline Gini & 1869 & 0.935 & 0.054 & 0.763 & 0.998 \\
\hline Products (log) & 1869 & 5.950 & 0.446 & 3.714 & 6.420 \\
\hline Theil & 1869 & 3.268 & 1.141 & 1.253 & 6.271 \\
\hline Theil V & 1869 & 2.790 & 0.888 & 1.058 & 5.358 \\
\hline Theil Between & 1869 & 0.478 & 0.448 & 0.007 & 2.736 \\
\hline NatRes $\%$ & 1869 & 0.482 & 0.289 & 0.038 & 0.990 \\
\hline Income pcap (log) & 1869 & 8.623 & 1.092 & 4.956 & 11.754 \\
\hline Total exports (log) & 1869 & 22.080 & 1.804 & 17.017 & 28.150 \\
\hline \multicolumn{6}{|c|}{ Panel C. OECD countries } \\
\hline $\mathrm{HHI}$ & 655 & 0.028 & 0.024 & 0.007 & 0.215 \\
\hline Gini & 655 & 0.801 & 0.059 & 0.670 & 0.950 \\
\hline Products (log) & 655 & 6.403 & 0.019 & 6.319 & 6.426 \\
\hline Theil & 655 & 1.621 & 0.443 & 0.880 & 3.548 \\
\hline Theil Within & 655 & 1.598 & 0.434 & 0.859 & 3.495 \\
\hline Theil Between & 655 & 0.024 & 0.019 & 0.000 & 0.108 \\
\hline NatRes \% exports & 655 & 0.203 & 0.163 & 0.026 & 0.750 \\
\hline Income pcap (log) & 655 & 10.238 & 0.414 & 9.127 & 11.080 \\
\hline Total exports (log) & 655 & 24.976 & 1.286 & 21.469 & 27.825 \\
\hline
\end{tabular}

Note: This table presents summary statistics of the variables used in the main estimation. Statistics are presented for all countries (Panel A), developing countries (Panel B) and developed countries (Panel C). 


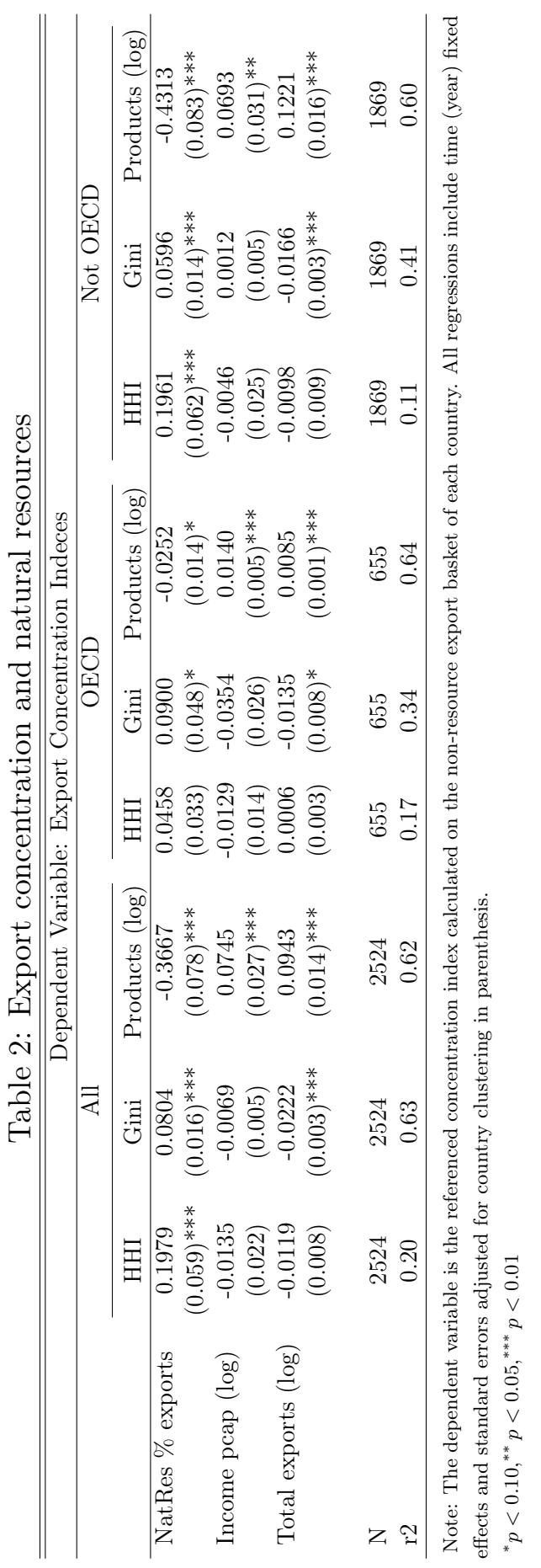




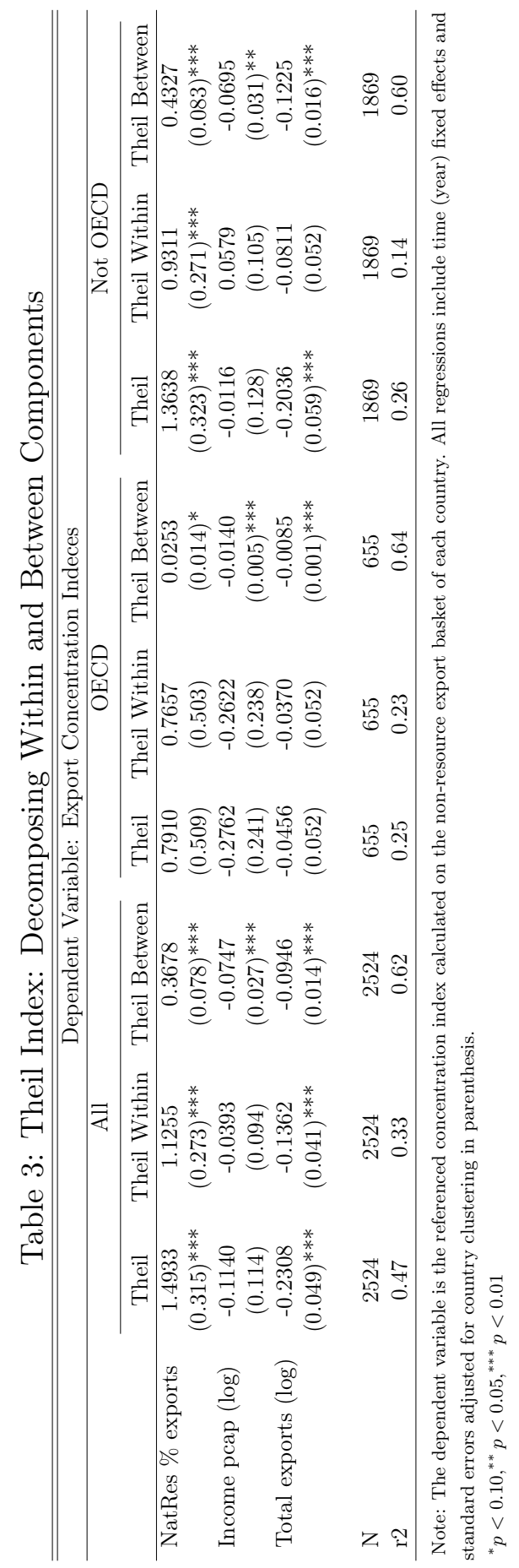


Table 4: 2SLS using oil and gas fields discoveries as IV

\begin{tabular}{lcccccc}
\hline \hline & \multicolumn{7}{c}{ Dependent Variable: } & Export Concentration Indeces & & \\
\hline & HHI & Gini & Products $(\log )$ & Theil & Theil Within & Theil Between \\
\hline NatRes \% exports & 0.2126 & 0.1407 & -0.3853 & 1.9256 & 1.5389 & 0.3867 \\
& $(0.078)^{* * *}$ & $(0.031)^{* * *}$ & $(0.196)^{*}$ & $(0.455)^{* * *}$ & $(0.404)^{* * *}$ & $(0.197)^{*}$ \\
Income pcap $(\log )$ & -0.0131 & -0.0049 & 0.0738 & -0.0995 & -0.0254 & -0.0741 \\
& $(0.022)$ & $(0.006)$ & $(0.028)^{* *}$ & $(0.119)$ & $(0.099)$ & $(0.029)^{* *}$ \\
Total exports $(\log )$ & -0.0113 & -0.0197 & 0.0935 & -0.2132 & -0.1194 & -0.0938 \\
& $(0.008)$ & $(0.003)^{* * *}$ & $(0.015)^{* * *}$ & $(0.049)^{* * *}$ & $(0.042)^{* * *}$ & $(0.016)^{* * *}$ \\
& & & & & & \\
$\mathrm{~N}$ & 2524 & 2524 & 2524 & 2524 & 2524 & 2524 \\
r2 & 0.20 & 0.59 & 0.62 & 0.46 & 0.31 & 0.62 \\
KP F Stat & 19.68 & 19.68 & 19.68 & 19.68 & 19.68 & 19.68 \\
\hline
\end{tabular}

Note: The dependent variable is the referenced concentration index calculated on the non-resource export basket of each country. All regressions include time (year) fixed effects and standard errors adjusted for country clustering in parenthesis.

${ }^{*} p<0.10,{ }^{* *} p<0.05,{ }^{* * *} p<0.01$ 
Table 5: 2SLS using commodity prices as IV

\begin{tabular}{lcccccc}
\hline \hline \multicolumn{7}{c}{ Dependent Variable: } \\
\hline & HHI & Gini & Products $(\log )$ & Theil & Theil Within & Theil Between \\
\hline NatRes \% exports & 0.4599 & 0.1638 & -0.6387 & 3.2148 & 2.5741 & 0.6407 \\
& $(0.083)^{* * *}$ & $(0.022)^{* * *}$ & $(0.135)^{* * *}$ & $(0.438)^{* * *}$ & $(0.373)^{* * *}$ & $(0.136)^{* * *}$ \\
Income pcap $(\log )$ & 0.0176 & -0.0036 & 0.0510 & 0.0183 & 0.0695 & -0.0512 \\
& $(0.019)$ & $(0.006)$ & $(0.025)^{* *}$ & $(0.125)$ & $(0.109)$ & $(0.025)^{* *}$ \\
Total exports $(\log )$ & -0.0007 & -0.0151 & 0.0786 & -0.1273 & -0.0485 & -0.0788 \\
& $(0.010)$ & $(0.003)^{* * *}$ & $(0.016)^{* * *}$ & $(0.062)^{* *}$ & $(0.053)$ & $(0.016)^{* * *}$ \\
& & & & & & \\
$\mathrm{~N}$ & 2096 & 2096 & 2096 & 2096 & 2096 & 2096 \\
r2 & 0.09 & 0.49 & 0.59 & 0.31 & 0.14 & 0.59 \\
KP F Stat & 64.12 & 64.12 & 64.12 & 64.12 & 64.12 & 64.12 \\
\hline
\end{tabular}

Note: The dependent variable is the referenced concentration index calculated on the non-resource export basket of each country. All regressions include time (year) fixed effects and standard errors adjusted for country clustering in parenthesis.

${ }^{*} p<0.10,{ }^{* *} p<0.05,{ }^{* * *} p<0.01$ 
Table 6: Commodity Price Spikes

\begin{tabular}{lcccc}
\hline \hline Commodity & Year $(\mathrm{t}=0)$ & $P_{(2010=100)}$ & $\Delta P$ & $\Delta P / \sigma_{P}$ \\
\hline Aluminum & 1988 & 146.50 & 50.75 & 2.55 \\
Aluminum & 1994 & 81.16 & 20.44 & 1.03 \\
Aluminum & 2006 & 131.51 & 31.91 & 1.60 \\
Aluminum & 2010 & 100.00 & 20.58 & 1.03 \\
Bananas & 1997 & 90.86 & 30.88 & 1.92 \\
Bananas & 2001 & 94.49 & 19.13 & 1.19 \\
Bananas & 2005 & 106.28 & 18.42 & 1.15 \\
Coal & 2004 & 75.01 & 32.01 & 1.40 \\
Coal & 2008 & 135.17 & 59.53 & 2.60 \\
Coal & 2010 & 100.00 & 24.19 & 1.05 \\
Cocoa & 2002 & 74.98 & 30.43 & 1.26 \\
Coffee & 1994 & 135.84 & 76.30 & 1.66 \\
Copper & 2006 & 99.21 & 43.54 & 1.81 \\
Copper & 2010 & 100.00 & 29.15 & 1.21 \\
Cotton A Index & 1987 & 95.96 & 28.58 & 1.64 \\
Cotton A Index & 1994 & 92.20 & 27.25 & 1.57 \\
Cotton A Index & 2003 & 76.96 & 17.98 & 1.03 \\
Cotton A Index & 2010 & 100.00 & 37.25 & 2.14 \\
Gold & 2010 & 100.00 & 17.64 & 1.04 \\
Liquified Natural Gas & 2008 & 112.29 & 38.07 & 1.77 \\
Meat beef & 2004 & 88.17 & 13.98 & 1.02 \\
Meat beef & 2010 & 100.00 & 18.45 & 1.35 \\
Meat sheep & 1996 & 68.75 & 15.10 & 1.00 \\
Meat sheep & 2010 & 100.00 & 16.58 & 1.10 \\
Oranges & 2001 & 75.27 & 31.08 & 1.62 \\
Rice & 2008 & 125.78 & 53.42 & 2.93 \\
Rubber & 2010 & 100.00 & 45.51 & 2.57 \\
Shrimp Mexico & 1997 & 186.73 & 37.50 & 1.12 \\
Soybean & 1988 & 76.68 & 16.89 & 1.04 \\
Soybean & 2007 & 88.94 & 24.22 & 1.49 \\
Soybean & 2008 & 114.63 & 25.70 & 1.58 \\
Tea & 1997 & 83.80 & 20.00 & 1.01 \\
Tobacco & 1989 & 91.80 & 20.70 & 1.87 \\
Tobacco & 1996 & 78.20 & 11.83 & 1.07 \\
Tobacco & 1997 & 94.85 & 16.65 & 1.50 \\
Tobacco & 2009 & 101.32 & 20.79 & 1.88 \\
Wheat & 109.74 & 26.52 & 1.55 \\
Wheat & 132.76 & 23.02 & 1.35 \\
Zinc & 168.56 & 95.67 & 3.21 \\
\hline
\end{tabular}

Note: This table presents all the ocassions used in the study as price spikes, which are those for which the change in price is higher than one standard deviation of the commodity price during the sample. The first column lists is the commodity, the second column presents the year of the spike (treated as $\mathrm{t}=0$ ), the third column presents the price of the commodity in the year $t=0$ (denoted by $P$, normalized by the price in 2010 being 100), the fourth column presents the nominal change in price between $\mathrm{t}=-1$ and $\mathrm{t}=0$ (denoted by $\Delta P$ ), and the last column presents the ratio between $\Delta P$ and the standard deviation of the price for that same commodity during the sample (denoted by $\sigma_{P}$ ). 
Table 7: Summary statistics price spikes DID sample

\begin{tabular}{|c|c|c|c|c|c|}
\hline Variable & $\mathrm{N}$ & Mean & Std. Dev. & Min & Max \\
\hline \multicolumn{6}{|c|}{ All Countries } \\
\hline HHI & 186 & 0.095 & 0.118 & 0.008 & 0.887 \\
\hline Gini & 186 & 0.902 & 0.072 & 0.711 & 0.997 \\
\hline Products $(\log )$ & 186 & 6.075 & 0.451 & 4.394 & 6.418 \\
\hline Theil & 186 & 2.692 & 0.989 & 0.989 & 6.022 \\
\hline Theil Within & 186 & 2.339 & 0.761 & 0.976 & 4.533 \\
\hline Theil Between & 186 & 0.353 & 0.452 & 0.008 & 2.043 \\
\hline Treatment $\left(\Delta N a t R e s_{i t}\right)$ & 186 & 0.013 & 0.049 & -0.112 & 0.158 \\
\hline Income pcap (log) & 186 & 8.886 & 1.195 & 6.183 & 11.129 \\
\hline Total exports (log) & 186 & 22.707 & 2.322 & 17.758 & 27.929 \\
\hline
\end{tabular}

Note: This table presents summary statistics of the variables used in the difference-in-differences estimation around unusual commodity price spikes, across all sample. 
Table 8: Export concentration and natural resources DID estimation

\begin{tabular}{lcccccc}
\hline \hline \multicolumn{7}{c}{ Dependent Variable: Export Concentration Indeces } \\
\hline & HHI & Gini & Products $(\log )$ & Theil & Theil Within & Theil Between \\
\hline Treatment $\times$ After & 1.1967 & 0.6987 & -0.5915 & 9.1266 & 8.5227 & 0.6024 \\
& $(0.463)^{* *}$ & $(0.139)^{* * *}$ & $(2.051)$ & $(3.450)^{* *}$ & $(2.271)^{* * *}$ & $(2.065)$ \\
After & 0.0042 & -0.0019 & -0.0864 & 0.0871 & 0.0005 & 0.0865 \\
& $(0.019)$ & $(0.007)$ & $(0.074)$ & $(0.148)$ & $(0.129)$ & $(0.074)$ \\
Income pcap $(\log )$ & -0.0685 & -0.0253 & -0.1342 & -0.4992 & -0.6355 & 0.1362 \\
& $(0.085)$ & $(0.023)$ & $(0.344)$ & $(0.617)$ & $(0.369)^{*}$ & $(0.347)$ \\
Total exports $(\log )$ & 0.0240 & 0.0043 & 0.1659 & 0.1526 & 0.3196 & -0.1669 \\
& $(0.031)$ & $(0.009)$ & $(0.097)^{*}$ & $(0.229)$ & $(0.158)^{* *}$ & $(0.097)^{*}$ \\
$\mathrm{~N}$ & & & & & 186 & 186 \\
$\mathrm{r} 2$ & 186 & 186 & 186 & 186 & 0.93 & 0.96 \\
\hline
\end{tabular}

Note: The dependent variable is the referenced concentration index calculated on the non-resource export basket of each country. All regressions include country and time (year) fixed effects. Standard errors adjusted for country clustering in parenthesis.

${ }^{*} p<0.10,{ }^{* *} p<0.05,{ }^{* * *} p<0.01$ 
Table 9: Summary statistics of product characteristics

\begin{tabular}{lccccc}
\hline \hline & & & & & \\
Variable & Obs & Mean & Std. Dev. & Min & Max \\
\hline Share Non-Resource Exports & 1878620 & 0.002 & 0.014 & 0.000 & 0.994 \\
Nat.Res. \% Exp & 1878620 & 0.433 & 0.293 & 0.022 & 0.994 \\
Capital Intensity & 1878620 & 0.775 & 0.100 & 0.528 & 0.928 \\
\hline
\end{tabular}


Table 10: Natural resources and capital-intensive products

\begin{tabular}{lccc}
\hline \hline \multicolumn{4}{c}{ Product share in non-natural resource export basket } \\
\hline & All countries & Non-OECD & OECD \\
\hline Nat.Res. \% Exp $\times$ Capital Intensity & 0.0133 & 0.0117 & 0.0180 \\
& $(0.002)^{* * *}$ & $(0.004)^{* * *}$ & $(0.003)^{* * *}$ \\
$\mathrm{~N}$ & 1878620 & 481400 & 1397220 \\
$\mathrm{r} 2$ & 0.14 & 0.30 & 0.16 \\
\hline
\end{tabular}

Note: All regressions include product-year and country-year fixed effects. Standard errors adjusted for country clustering are reported in parenthesis.

${ }^{*} p<0.10,{ }^{* *} p<0.05,{ }^{* * *} p<0.01$ 
Table 11: Concentration and capital content export basket

\begin{tabular}{lccc}
\hline \hline \multicolumn{4}{c}{ Dependent Variable: Export Concentration Indeces } \\
\hline NatRes \% exports $\times$ Cap. content & -2.8499 & -0.0686 & 5.2533 \\
& $(0.429)^{* * *}$ & $(0.070)$ & $(1.422)^{* * *}$ \\
NatRes \% exports $\times$ Cap. content sq. & 2.6434 & 0.0712 & -4.2045 \\
& $(0.418)^{* * *}$ & $(0.067)$ & $(1.402)^{* * *}$ \\
NatRes \% exports & 0.6207 & 0.0025 & -1.7030 \\
& $(0.133)^{* * *}$ & $(0.026)$ & $(0.478)^{* * *}$ \\
Cap. content & 0.0117 & -0.0450 & -0.2440 \\
& $(0.109)$ & $(0.030)$ & $(0.356)$ \\
Income pcap $(\log )$ & -0.0018 & 0.0047 & -0.1392 \\
& $(0.022)$ & $(0.008)$ & $(0.090)$ \\
Total exports $(\log )$ & 0.0104 & -0.0057 & 0.1734 \\
& $(0.008)$ & $(0.003)^{*}$ & $(0.039)^{* * *}$ \\
N & & & \\
r2 & 2524 & 2524 & 2524 \\
\hline
\end{tabular}

Note: Note: The dependent variable is the referenced concentration index calculated on the nonresource export basket of each country. All regressions include country and year fixed effects. Standard errors adjusted for country clustering are reported in parenthesis.

${ }^{*} p<0.10,{ }^{* *} p<0.05,{ }^{* * *} p<0.01$ 


\section{A Mathematical Appendix}

\section{A.1 Domestic productivity cutoff and number of varieties}

In this section we develop comparative statistics focusing on the domestic productivity cutoff. Let a hat $\hat{\bullet}$ over a variable represent a percentage change. As in ?, totally differentiating (4) we get:

$$
\hat{\phi}_{D i}=\frac{1}{\sigma-1}\left(\sigma \hat{W}_{i}-\hat{E}_{i}^{H}-(\sigma-1) \hat{P}_{i}^{H}\right)
$$

Let $s_{X i} \equiv \frac{X_{i}}{D_{i}+X_{i}}$ represent the export share of sales in industry $i$. Totally differentiating the free entry condition (6) and substituting (4) and (5) gives:

$$
0=\left(1-s_{X i}\right)\left(\hat{E}_{i}^{H}+(\sigma-1) \hat{P}_{i}^{H}\right)-\sigma \hat{W}_{i}
$$

Substituting 20 into (19) gives:

$$
\hat{\phi}_{D i}=-\left(\frac{\sigma}{\sigma-1}\right)\left(\frac{s_{X i}}{1-s_{X i}}\right) \hat{W}_{i}
$$

A visualization of this change is in Figure 1. As opposed to the export productivity cutoff, the domestic cutoff is decreasing in wages. This implies, the number of firms in the domestic market increase, similarly to the model suggested by Ostenstad and Vermeulen (2016), who endogenize the nontradable sector. In other words, following a Dutch disease, the tradable sector shrinks and the non-tradable sector becomes larger, consistent with what the conventional wisdom. The total number of varieties produced in each industry equals the entrants who have $\phi \geq \phi_{D i}$. This is completely 
determined by the cutoff and can be written as:

$$
N_{i}\left[1-G\left(\phi_{D i}\right)\right]
$$

Because the domestic cutoff decreases after a windfall, total product variety in the domestic market increases.

[Figure A1 about here.]

\section{A.2 Derivation of equation (7)}

Rearranging (3) give the inverse demand function:

$$
p_{i}=E_{i}^{\frac{1}{\sigma}} P_{i}^{\frac{\sigma-1}{\sigma}} q_{i}^{\frac{-1}{\sigma}}
$$

Let $l_{D}$ and $l_{X}$ represent the amount of labor a firm uses in domestic production and export production, respectively. We can express domestic revenue as a function of labor

$$
r_{D i}=E_{i}^{\frac{1}{\sigma}} P_{i}^{\frac{\sigma-1}{\sigma}}\left(\phi \frac{l_{D}}{\beta_{i}}\right)^{\frac{\sigma-1}{\sigma}}
$$

Similarly, export revenue is:

$$
r_{X i}=E_{i}^{\frac{1}{\sigma}} P_{i}^{\frac{\sigma-1}{\sigma}}\left(\phi \frac{l_{X}}{\tau \beta_{i}}\right)^{\frac{\sigma-1}{\sigma}}
$$

Firms will allocate labor such that the marginal revenue associated with domestic production equals the marginal revenue associated with export pro- 
duction. This gives:

$$
l_{X}=\left(\frac{E_{I}^{F}}{E_{I}^{H}}\right)\left(\frac{P_{i}^{F}}{P_{i}^{H}}\right)^{\sigma-1} \tau^{1-\sigma} l_{D} .
$$

Let $l=l_{D}+l_{X}$ represent the firm's total labor force. We have:

$$
\begin{aligned}
& l_{D}=\frac{E_{i}^{H}\left(P_{i}^{H}\right)^{\sigma-1}}{E_{i}^{H}\left(P_{i}^{H}\right)^{\sigma-1}+\tau^{1-\sigma} E_{i}^{F}\left(P_{i}^{F}\right)^{\sigma-1}} l \\
& l_{X}=\frac{\tau^{1-\sigma} E_{i}^{F}\left(P_{i}^{F}\right)^{\sigma-1}}{E_{i}^{H}\left(P_{i}^{H}\right)^{\sigma-1}+\tau^{1-\sigma} E_{i}^{F}\left(P_{i}^{F}\right)^{\sigma-1}} l .
\end{aligned}
$$

Substituting these expressions into the total revenue function $r=r_{D}+\nVdash_{X} r_{X}$ and taking the first-order condition with respect to labor gives equation (7).

\section{A.3 Calculating HHI}

Equation 12 can be rewritten as

$$
\begin{aligned}
Q_{X i} & =N_{i} \tau^{1-\sigma} E_{i}^{F}\left(P_{i}^{F}\right)^{\sigma-1}\left(\frac{\sigma}{\sigma-1}\right)^{-\sigma} W_{i}^{-\sigma} \int_{\phi_{X i}} \phi^{\sigma} d G(\phi) \\
& =N_{i} \tau^{1-\sigma} E_{i}^{F}\left(P_{i}^{F}\right)^{\sigma-1}\left(\frac{\sigma}{\sigma-1}\right)^{-\sigma} W_{i}^{-\sigma} \int_{\phi_{X i}} \phi^{\sigma} \theta \phi^{-\theta-1} d \phi \\
& =N_{i} \tau^{1-\sigma} E_{i}^{F}\left(P_{i}^{F}\right)^{\sigma-1}\left(\frac{\sigma}{\sigma-1}\right)^{-\sigma} W_{i}^{-\sigma} \frac{\theta}{\theta-\sigma} \phi_{X i}^{\sigma-\theta} .
\end{aligned}
$$

So $Q_{X 1} / Q_{X 2}$ is

$$
\frac{Q_{X 1}}{Q_{X 2}}=\frac{N_{1}}{N_{2}} \frac{E_{1}^{F}}{E_{2}^{F}}\left(\frac{P_{1}^{F}}{P_{2}^{F}}\right)^{\sigma-1}\left(\frac{W_{1}}{W_{2}}\right)^{-\sigma}\left(\frac{\phi_{X 1}}{\phi_{X 2}}\right)^{\sigma-\theta}
$$

and substituting this result into (13) gives (14). 


\section{B Primary Products}

Table A1 lists all products considered as Primary Products by Lall (2000), based on their 3 digit classification. This category (Primary Products) is the one we use to classify certain export products as natural resources, unless otherwise specified.

[Table A1 about here.]

\section{Variance Decomposition}

Table A2 presents the variance decomposition of our variable of interest -the share of natural resources in the country's export basket- throughout Section 4. It shows that across years there is very little within-country variation.

[Table A2 about here.]

\section{Concentration Measures}

Below we describe the different indexes used to measure export concentration:

- Gini coefficient: The Gini coefficient is a measure of statistical dispersion commonly used to represent the distribution of income. We use the same formula as Steingress (2015). Let $k$ index a product among $N$ products existing in the world economy; $R k$ be the corresponding export sales revenue of a given country. The export Gini in this country is given by: 


$$
G=\frac{2}{N} \frac{\left(\sum_{k=1}^{n} k R k\right)}{\sum_{k=1}^{n} R k}-\frac{N+1}{N}
$$

where export revenues of product $k, R k$, are indexed in increasing order, i.e. $R_{k}<R_{k+1}$, and $N$ denotes the total number of products in the world. The Gini coefficient lies between zero (perfect equality) and one (complete inequality).

- Herfindahl-Hirschman Index (HHI): A measure of market concentration commonly used to measure market power of monopolies or oligopolies. It is calculated by summing the square of the share of every product $i$ in the non-resource export basket of a country $\left(S_{i}\right)$ within a certain year. The HHI index ranges from zero (perfect diversification) to 10,000 (perfect concentration). We have normalized the HHI so that it ranges between zero and one, using:

$$
H H I=\frac{\sum_{i=1}^{n} S_{i}^{2}-\left(\frac{1}{n}\right)}{1-\left(\frac{1}{n}\right)}
$$

where $n$ is the total number of products of exported by the country.

- Theil index: First introduced by Henri Theil (1967), has been applied to a wide array of purposes within social sciences. The Theil index can be calculated as a weighted average of the log difference from the mean export revenue $(\bar{R})$ as defined by the following formula:

$$
T=\frac{1}{N} \sum_{k \in N} \frac{R k}{\bar{R}} \ln \left(\frac{R k}{\bar{R}}\right)
$$


We take advantage of the decomposition properties of the Theil index to broaden our understanding on how much of the impact of Dutch disease on non-resource export concentration is due to changes in the relative size of existing products (within or intensive margin), and how much is due to changes in the number of export products (between or extensive margin). Following Cadot et al., 2011 we have decomposed the Theil index using the following formulas:

$$
\begin{gathered}
T=\frac{1}{N} \sum_{k \in N} \frac{R k}{\bar{R}} \ln \left(\frac{R k}{\bar{R}_{x}}\right) \\
T_{b}=\frac{N}{N_{x}}
\end{gathered}
$$

where $N_{x}$ denotes the number of exported products and $\bar{R}_{x}$ represents the mean value of exported products. Our corresponding diversification indexes are then $\left(1-T_{w}\right)$ and $\left(1-T_{b}\right)$.

\section{E First Stage 2SLS Regressions}

\section{E.1 Discovery of gas and oil fields as instrument}

Tables A3 present results for the first stage regressions that use oil and gas fields discoveries as an instrument to the size of natural resources in the country's export basket. Column 1 presents results for all the sample, which corresponds to the sample used in Table 4 . Columns 2 and 3 present results for the sample that uses OECD and non-OECD countries, respectively, that 
correspond to the 2SLS results presented in Tables A7 and A8.

[Table A3 about here.]

\section{E.2 Commodity prices as instrument}

Tables A4 present results for the first stage regressions that use commodity prices, as well as the share of the most important commodity -that for which the price is used- within the natural resource export basket, as instruments to the size of natural resources in the country's export basket. Column 1 presents results for all the sample, which corresponds to the sample used in Table 5. Columns 2 and 3 present results for the sample that uses OECD and non-OECD countries, respectively, that correspond to the 2SLS results presented in Tables A7 and A8.

[Table A4 about here.]

\section{F 2SLS OECD vs. non-OECD samples}

\section{F.1 Discovery of gas and oil fields as instrument}

Tables A5 and A6 replicate Table 4 in the main body of the paper, splitting the sample into OECD and non-OECD countries, respectively. As expected, the results are mostly driven by developing (non-OECD) countries.

[Table A5 about here.]

[Table A6 about here.] 


\section{F.2 Commodity prices as instrument}

Tables A7 and A8 replicate Table 5 in the main body of the paper, splitting the sample into OECD and non-OECD countries, respectively. As expected, the results are mostly driven by developing (non-OECD) countries.

[Table A7 about here.]

[Table A8 about here.]

\section{G Using more liberal definition for non-resource products}

Table A9 replicates the results of Table 10 using a more liberal definition of natural resources to populate the sample. In this case, we also exclude products that are defined as "resource-based" by Lall (2000), on top of those defined as "primary products". The results are robust to their exclusion.

[Table A9 about here.] 
Figure A1: Change in the domestic cutoff after a resource windfall

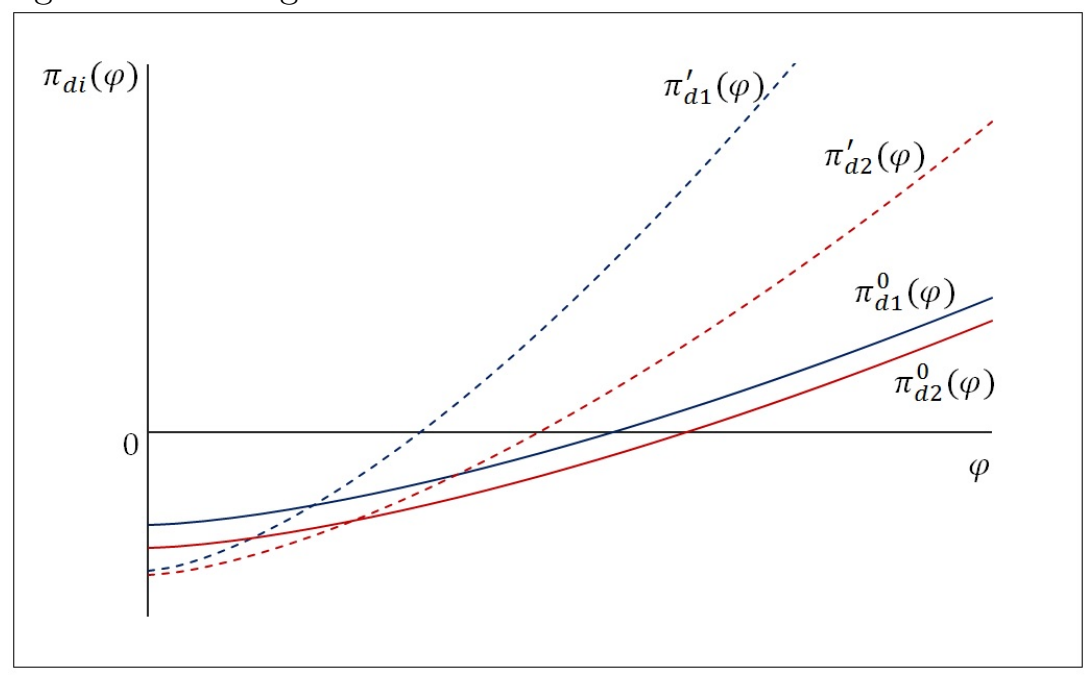

Profits in the domestic sector $\phi_{d i}(\phi)$ are represented on the vertical axis and the productivity parameter $\phi$ is represented on the horizontal axis. Profits for labor-intensive Industry 1 are represented in blue while profits for capitalintensive Industry 2 are represented in red. The pre-windfall equilibrium is represented with a naught superscript and a solid line while the post-windfall equilibrium is represented with a prime superscript and a dashed line. The fixed costs for both industries increase as a result of the increased wage rate but the slopes of each profit curve increases as a result of increased expenditure.

These changes are larger in magnitude for the labor-intensive industry than for the capital-intensive industry. 
Table A1: Primary products (SITC 3 digit) as classified by Lall (2000)

\begin{tabular}{|c|c|c|}
\hline Primary Products (PP) & Resource Based: AGRO-BASED & Resource Based: OTHER \\
\hline 001 LIVE ANIMALS FOR FOOD & 012 MEAT DRIED,SALTED,SMOKED & 281 IRON ORE,CONCENTRATES \\
\hline 011 MEAT FRESH,CHILLD,FROZEN & 014 MEAT PREPD,PRSVD,NES ETC & 282 IRON AND STEEL SCRAP \\
\hline 022 MILK AND CREAM & 023 BUTTER & 286 URANIUM,THORIUM ORE,CONC \\
\hline 025 EGGS,BIRDS,FRESH,PRSRVD & 024 CHEESE AND CURD & 287 BASE METAL ORES,CONC NES \\
\hline 034 FISH,FRESH,CHILLED,FROZN & 035 FISH SALTED,DRIED,SMOKED & 288 NONFERR METAL SCRAP NES \\
\hline 036 SHELL FISH FRESH,FROZEN & 037 FISH ETC PREPD,PRSVD NES & 289 PREC MTAL ORES,WASTE NES \\
\hline 041 WHEAT ETC UNMILLED & 046 WHEAT ETC MEAL OR FLOUR & 323 BRIQUETS,COKE,SEMI-COKE \\
\hline 042 RICE & 047 OTHER CEREAL MEALS,FLOUR & 334 PETROLEUM PRODUCTS,REFIN \\
\hline 043 BARLEY UNMILLED & 048 CEREAL ETC PREPARATIONS & 335 RESIDUAL PETRLM PROD NES \\
\hline 044 MAIZE UNMILLED & 056 VEGTBLES ETC PRSVD,PREPD & 411 ANIMAL OILS AND FATS \\
\hline 045 CEREALS NES UNMILLED & 058 FRUIT PRESERVED,PREPARED & 511 HYDROCARBONS NES,DERIVS \\
\hline 054 VEG ETC FRSH,SMPLY PRSVD & 061 SUGAR AND HONEY & 511 HYDROCARBONS NES,DERIVS \\
\hline 057 FRUIT,NUTS,FRESH,DRIED & 062 SUGAR CANDY NON-CHOCLATE & 514 NITROGEN-FNCTN COMPOUNDS \\
\hline 071 COFFEE AND SUBSTITUTES & 073 CHOCOLATE AND PRODUCTS & 515 ORG-INORG COMPOUNDS ETC \\
\hline $072 \mathrm{COCOA}$ & 098 EDIBLE PRODCTS,PREPS NES & 516 OTHER ORGANICCHEMICALS \\
\hline 074 TEA AND MATE & 111 NON-ALCOHL BEVERAGES NES & 522 INORG ELEMNTS,OXIDES,ETC \\
\hline 075 SPICES & 112 ALCOHOLIC BEVERAGES & 523 OTHR INORGCHEMICALS \\
\hline 081 FEEDING STUFF FOR ANIMLS & 122 TOBACCO,MANUFACTURED & 531 SYNT DYE,NATINDGO,LAKES \\
\hline 091 MARGARINE AND SHORTENING & 233 RUBBER,SYNTHTIC,RECLAIMD & 532 DYES NES,TANNINGPROD \\
\hline 121 TOBACCO UNMNFCTRD,REFUSE & 247 OTH WOOD ROUGH,SQUARED & 551 ESSENTL OILS,PERFUME,ETC \\
\hline 211 HIDES,SKINS,EXC FURS,RAW & 248 WOOD SHAPED,SLEEPERS & 592 STARCH,INULIN,GLUTEN,ETC \\
\hline 212 FURSKINS,RAW & 251 PULP AND WASTE PAPER & 661 LIME,CEMENT,BLDG PRODS \\
\hline 222 SEEDS FOR'SOFT'FIXED OIL & 264 JUTE,OTH TEX BAST FIBRES & 662 CLAY,REFRACTORY BLDGP \\
\hline 223 SEEDS FOR OTH FIXED OILS & 265 VEG FIBRE,EXCL COTN,JUTE & 663 MINERAL MANUFCTURESNES \\
\hline 232 NATURAL RUBBER,GUMS & 269 WASTE OF TEXTILE FABRICS & 664 GLASS \\
\hline 244 CORK,NATURAL,RAW,WASTE & 423 FIXED VEG OILS,SOFT & 667 PEARL,PREC-,SEMI-P STONE \\
\hline 245 FUEL WOOD NES, CHARCOAL & 424 FIXED VEG OIL NONSOFT & 688 URANIUM,THORIUM,ALLOYS \\
\hline 246 PULPWOOD,CHIPS,WOODWASTE & 431 PROCESD ANML VEG OIL,ETC & 689 NON-FER BASEMETALS \\
\hline 261 SILK & 621 MATERIALS OF RUBBER & \\
\hline 263 COTTON & 625 RUBBER TYRES, TUBES ETC & \\
\hline 268 WOOL(EXC TOPS),ANML HAIR & 628 RUBBER ARTICLES NES & \\
\hline 271 FERTILIZERS,CRUDE & 633 CORK MANUFACTURES & \\
\hline 273 STONE,SAND AND GRAVEL & 634 VENEERS,PLYWOOD,ETC & \\
\hline 274 SULPHUR,UNRSTD IRN PYRTE & 635 WOOD MANUFACTURES NES & \\
\hline 277 NATURAL ABRASIVES NES & 641 PAPER AND PAPERBOARD & \\
\hline \multicolumn{3}{|l|}{278 OTHER CRUDE MINERALS } \\
\hline \multicolumn{3}{|l|}{291 CRUDE ANIMAL MTRIALS NES } \\
\hline \multicolumn{3}{|l|}{292 CRUDE VEG MATERIALS NES } \\
\hline \multicolumn{3}{|l|}{322 COAL,LIGNITE AND PEAT } \\
\hline \multicolumn{3}{|l|}{333 CRUDE PETROLEUM } \\
\hline \multicolumn{3}{|l|}{341 GAS,NATURAL AND MANUFCTD } \\
\hline \multicolumn{3}{|l|}{681 SILVER,PLATINUM,ETC } \\
\hline \multicolumn{3}{|l|}{682 COPPER EXC CEMENT COPPER } \\
\hline \multicolumn{3}{|l|}{683 NICKEL } \\
\hline \multicolumn{3}{|l|}{684 ALUMINIUM } \\
\hline \multicolumn{3}{|l|}{685 LEAD } \\
\hline \multicolumn{3}{|l|}{$686 \mathrm{ZINC}$} \\
\hline 687 TIN & & \\
\hline
\end{tabular}


Table A2: Variance Decomposition: Nat. Res. as \% of Exports

\begin{tabular}{lccccc}
\hline \hline Source & SS & df & MS & F & Prob > F \\
\hline Between Country & 246.905 & 127 & 1.944 & 199.693 & 0.000 \\
Within Country & 30.287 & 3111 & 0.010 & & \\
Total & 277.193 & 3238 & 0.086 & & \\
\hline Estimated SD between & 0.277 & & & & \\
Estimated SD within & 0.099 & & & & \\
Estimated SD Country effect & 0.294 & & & & \\
Estimated realibity Country & 0.942 & & & & \\
Evaluated at n= & 25.305 & & & & \\
\hline Correlation & 0.888 & & & & \\
Number of Observations & 3239 & & & & \\
R-squared & 0.891 & & & & \\
\hline
\end{tabular}


Table A3: First stage 2SLS, discoveries as IV

\begin{tabular}{lccc}
\hline \hline \multicolumn{3}{c}{ Dependent Variable: } & Natural Resources share in country's export basket \\
\hline discovery & All & OECD & Non OECD \\
& 0.2341 & 0.1787 & 0.1871 \\
Income pcap $(\log )$ & $(0.053)^{* * *}$ & $(0.080)^{* *}$ & $(0.059)^{* * *}$ \\
& -0.0260 & 0.1048 & -0.0146 \\
Total exports (log) & $(0.030)$ & $(0.097)$ & $(0.034)$ \\
& -0.0489 & -0.0555 & -0.0298 \\
& $(0.015)^{* * *}$ & $(0.024)^{* *}$ & $(0.020)$ \\
$\mathrm{N}$ & & & \\
$\mathrm{r} 2$ & 2524 & 655 & 1869 \\
\hline
\end{tabular}

Note: The dependent variable is the share of natural resource exports in the country's export basket. Column 1 presents first stage results using the sample with all countries, while Columns 2 and 3 present first stage results using the sample of OECD and non-OECD countries, respectively. All regressions include time (year) fixed effects and standard errors adjusted for country clustering in parenthesis.

${ }^{*} p<0.10,{ }^{* *} p<0.05,{ }^{* * *} p<0.01$ 
Table A4: First stage 2SLS, commodity prices as IV

\begin{tabular}{lccc}
\hline \hline \multicolumn{4}{c}{ Dependent Variable: Natural Resources share in country's export basket } \\
\hline & All & OECD & Non OECD \\
\hline Price of Main Commodity Export (2010 USD, 2010=100) & -0.0017 & -0.0008 & -0.0019 \\
& $(0.001)^{* *}$ & $(0.001)$ & $(0.001)^{* *}$ \\
commoditypnatres & 0.5954 & 0.6026 & 0.5904 \\
& $(0.060)^{* * *}$ & $(0.151)^{* * *}$ & $(0.063)^{* * *}$ \\
Income pcap $(\log )$ & -0.0424 & 0.1362 & -0.0496 \\
& $(0.024)^{*}$ & $(0.076)^{*}$ & $(0.026)^{*}$ \\
Total exports $(\log )$ & -0.0268 & -0.0489 & -0.0220 \\
& $(0.013)^{* *}$ & $(0.021)^{* *}$ & $(0.016)$ \\
N & & & \\
r2 & 2096 & 487 & 1609 \\
\hline
\end{tabular}

Note: The dependent variable is the share of natural resource exports in the country's export basket. Column 1 presents first stage results using the sample with all countries, while Columns 2 and 3 present first stage results using the sample of OECD and non-OECD countries, respectively. All regressions include time (year) fixed effects and standard errors adjusted for country clustering in parenthesis. ${ }^{*} p<0.10,{ }^{* *} p<0.05,{ }^{* * *} p<0.01$ 
Table A5: 2SLS estimation using discoveries as IV (OECD)

\begin{tabular}{lcccccc}
\hline \hline \multicolumn{7}{c}{ Dependent Variable: Concentration Indeces } \\
\hline & HHI & Gini & Products $(\log )$ & Theil & Theil Within & Theil Between \\
\hline NatRes \% exports & 0.0084 & 0.0951 & -0.0162 & 0.3543 & 0.3381 & 0.0162 \\
& $(0.041)$ & $(0.077)$ & $(0.036)$ & $(0.727)$ & $(0.746)$ & $(0.036)$ \\
Income pcap $(\log )$ & -0.0083 & -0.0360 & 0.0128 & -0.2219 & -0.2091 & -0.0129 \\
& $(0.014)$ & $(0.027)$ & $(0.006)^{* *}$ & $(0.256)$ & $(0.253)$ & $(0.006)^{* *}$ \\
Total exports $(\log )$ & -0.0014 & -0.0132 & 0.0090 & -0.0690 & -0.0600 & -0.0090 \\
& $(0.003)$ & $(0.007)^{*}$ & $(0.002)^{* * *}$ & $(0.058)$ & $(0.058)$ & $(0.002)^{* * *}$ \\
$\mathrm{~N}$ & 655 & 655 & 655 & 655 & 655 & 655 \\
$\mathrm{r} 2$ & 0.11 & 0.34 & 0.64 & 0.23 & 0.21 & 0.64 \\
KP F Stat & 5.00 & 5.00 & 5.00 & 5.00 & 5.00 & 5.00 \\
\hline Note: The dependent variable is the referenced concentration index calculated on the non-resource export basket of \\
each country. All regressions include time (year) fixed effects and standard errors adjusted for country clustering in \\
parenthesis. \\
${ }^{*} p<0.10,{ }^{* *} p<0.05,{ }^{* * *} p<0.01$
\end{tabular}


Table A6: 2SLS estimation using discoveries as IV (non-OECD)

\begin{tabular}{lcccccc}
\hline \hline & \multicolumn{7}{c}{ Dependent Variable: Concentration Indeces } \\
\hline & HHI & Gini & Products $(\log )$ & Theil & Theil Within & Theil Between \\
\hline NatRes \% exports & 0.1948 & 0.0784 & -0.6757 & 1.5989 & 0.9204 & 0.6784 \\
& $(0.116)^{*}$ & $(0.040)^{*}$ & $(0.301)^{* *}$ & $(0.681)^{* *}$ & $(0.633)$ & $(0.302)^{* *}$ \\
Income pcap $(\log )$ & -0.0046 & 0.0016 & 0.0645 & -0.0070 & 0.0577 & -0.0647 \\
& $(0.025)$ & $(0.005)$ & $(0.033)^{*}$ & $(0.130)$ & $(0.105)$ & $(0.033)^{*}$ \\
Total exports $(\log )$ & -0.0098 & -0.0162 & 0.1171 & -0.1988 & -0.0813 & -0.1175 \\
& $(0.009)$ & $(0.003)^{* * *}$ & $(0.019)^{* * *}$ & $(0.057)^{* * *}$ & $(0.053)$ & $(0.019)^{* * *}$ \\
& & & & & & \\
N & 1869 & 1869 & 1869 & 1869 & 1869 & 1869 \\
r2 & 0.11 & 0.40 & 0.57 & 0.25 & 0.14 & 0.57 \\
KP F Stat & 9.89 & 9.89 & 9.89 & 9.89 & 9.89 & 9.89 \\
\hline
\end{tabular}

Note: The dependent variable is the referenced concentration index calculated on the non-resource export basket of each country. All regressions include time (year) fixed effects and standard errors adjusted for country clustering in parenthesis. ${ }^{*} p<0.10,{ }^{* *} p<0.05,{ }^{* * *} p<0.01$ 
Table A7: 2SLS estimation using commodity prices as IV (OECD)

\begin{tabular}{lcccccc}
\hline \hline \multicolumn{7}{c}{ Dependent Variable: Export Concentration Indeces } \\
\hline & HHI & Gini & Products $(\log )$ & Theil & Theil Within & Theil Between \\
\hline NatRes \% exports & 0.0084 & 0.0951 & -0.0162 & 0.3543 & 0.3381 & 0.0162 \\
& $(0.041)$ & $(0.077)$ & $(0.036)$ & $(0.727)$ & $(0.746)$ & $(0.036)$ \\
Income pcap $(\log )$ & -0.0083 & -0.0360 & 0.0128 & -0.2219 & -0.2091 & -0.0129 \\
& $(0.014)$ & $(0.027)$ & $(0.006)^{* *}$ & $(0.256)$ & $(0.253)$ & $(0.006)^{* *}$ \\
Total exports (log) & -0.0014 & -0.0132 & 0.0090 & -0.0690 & -0.0600 & -0.0090 \\
& $(0.003)$ & $(0.007)^{*}$ & $(0.002)^{* * *}$ & $(0.058)$ & $(0.058)$ & $(0.002)^{* * *}$ \\
$\mathrm{~N}$ & 655 & 655 & 655 & 655 & 655 & 655 \\
r2 & 0.11 & 0.34 & 0.64 & 0.23 & 0.21 & 0.64 \\
KP F Stat & 5.00 & 5.00 & 5.00 & 5.00 & 5.00 & 5.00 \\
\hline Note: The dependent variable is the referenced concentration index calculated on the non-resource export basket of \\
each country. All regressions include time (year) fixed effects and standard errors adjusted for country clustering in \\
parenthesis. \\
${ }^{*} p<0.10,{ }^{* *} p<0.05,{ }^{* * *} p<0.01$
\end{tabular}


Table A8: 2SLS estimation using commodity prices as IV (non-OECD)

\begin{tabular}{lcccccc}
\hline \hline & \multicolumn{7}{c}{ Dependent Variable: Export Concentration Indeces } & \\
\hline & HHI & Gini & Products $(\log )$ & Theil & Theil Within & Theil Between \\
\hline NatRes \% exports & 0.1948 & 0.0784 & -0.6757 & 1.5989 & 0.9204 & 0.6784 \\
& $(0.116)^{*}$ & $(0.040)^{*}$ & $(0.301)^{* *}$ & $(0.681)^{* *}$ & $(0.633)$ & $(0.302)^{* *}$ \\
Income pcap $(\log )$ & -0.0046 & 0.0016 & 0.0645 & -0.0070 & 0.0577 & -0.0647 \\
& $(0.025)$ & $(0.005)$ & $(0.033)^{*}$ & $(0.130)$ & $(0.105)$ & $(0.033)^{*}$ \\
Total exports $(\log )$ & -0.0098 & -0.0162 & 0.1171 & -0.1988 & -0.0813 & -0.1175 \\
& $(0.009)$ & $(0.003)^{* * *}$ & $(0.019)^{* * *}$ & $(0.057)^{* * *}$ & $(0.053)$ & $(0.019)^{* * *}$ \\
& & & & & & \\
N & 1869 & 1869 & 1869 & 1869 & 1869 & 1869 \\
r2 & 0.11 & 0.40 & 0.57 & 0.25 & 0.14 & 0.57 \\
KP F Stat & 9.89 & 9.89 & 9.89 & 9.89 & 9.89 & 9.89 \\
\hline
\end{tabular}

Note: The dependent variable is the referenced concentration index calculated on the non-resource export basket of each country. All regressions include time (year) fixed effects and standard errors adjusted for country clustering in parenthesis. ${ }^{*} p<0.10,{ }^{* *} p<0.05,{ }^{* * *} p<0.01$ 
Table A9: Natural resources and capital-intensive products

\begin{tabular}{lccc}
\hline \hline \multicolumn{4}{c}{ Product share in non-natural resource export basket } \\
\hline & All countries & Non-OECD & OECD \\
\hline Nat.Res. \% Exp $\times$ Capital Intensity & 0.0079 & 0.0132 & 0.0049 \\
& $(0.003)^{* *}$ & $(0.004)^{* * *}$ & $(0.005)$ \\
$\mathrm{N}$ & & & \\
$\mathrm{r} 2$ & 1363619 & 1014189 & 349430 \\
\hline
\end{tabular}

Note: All regressions include product-year and country-year fixed effects. Standard errors adjusted for country clustering are reported in parenthesis.

${ }^{*} p<0.10,{ }^{* *} p<0.05,{ }^{* * *} p<0.01$ 